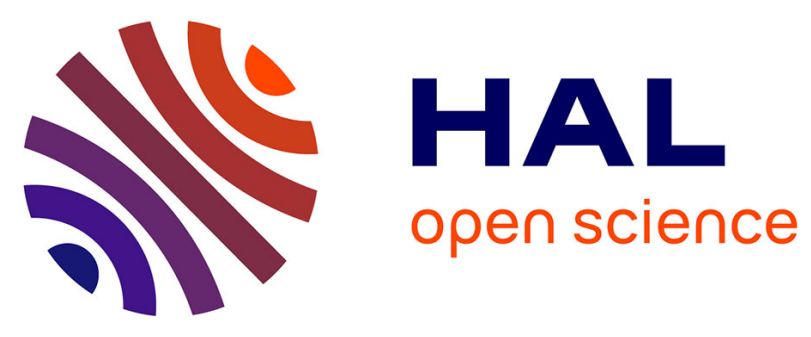

\title{
An investigation of Neolithic settlement pattern and plant exploitation at Dikili Tash
}

\author{
Dimitra Malamidou, Maria Ntinou, Soultana-Maria Valamoti, Zoï Tsirtsoni, \\ Haïdo Koukouli-Chryssanthaki, Pascal Darcque
}

\section{To cite this version:}

Dimitra Malamidou, Maria Ntinou, Soultana-Maria Valamoti, Zoï Tsirtsoni, Haïdo KoukouliChryssanthaki, et al.. An investigation of Neolithic settlement pattern and plant exploitation at Dikili Tash: Reconsidering old and new data from the late 5th millenium BC settlement. Evita Kalogeropoulou; Tuna Kalayci; Evagelia Karimali; Apostolos Sarris. Communities, Landscapes and Interaction in Neolithic Greece. Proceedings of the International Conference, 29-30 May 2015, Rethymno, 20, Berghahn Books, p.60-80, 2018, International Monographs in Prehistory: Archaeological Series, 978-1-87962-148-0. 10.2307/j.ctvw049k3.11 . hal-02859953

\section{HAL Id: hal-02859953 \\ https://hal.parisnanterre.fr/hal-02859953}

Submitted on 8 Jun 2020

HAL is a multi-disciplinary open access archive for the deposit and dissemination of scientific research documents, whether they are published or not. The documents may come from teaching and research institutions in France or abroad, or from public or private research centers.
L'archive ouverte pluridisciplinaire HAL, est destinée au dépôt et à la diffusion de documents scientifiques de niveau recherche, publiés ou non, émanant des établissements d'enseignement et de recherche français ou étrangers, des laboratoires publics ou privés. 


\section{An Investigation of Neolithic Settlement Pattern and Plant Exploitation at Dikili Tash: Reconsidering Old and New Data from the Late 5th Millennium B.C. Settlement}

\section{Dimitra Malamidou, Maria Ntinou, Soultana-Maria Valamoti, Zoï Tsirtsoni, Haïdo Koukouli-Chryssanthaki, and Pascal Darcque}

\begin{abstract}
Dikili Tash appears today to be one of the prehistoric settlements with the longest occupational sequences in the Aegean and the Balkans (ca. 6500 1100 B.C.). In the last fifty years, research at the site and in the surrounding Philippi Plain has offered information for understanding the role of natural and anthropogenic processes in tell formation and landscape change. In this paper, we discuss a particular time-window of this long sequence, the years around 4300-4200 cal B.C., for which we now have a large range of high-resolution data from secure contexts. Excavation of large areas in Sector 6 allowed for the exploration of the spatial arrangement and household organization of the settlement in the above period. The buildings that were fully excavated in Sector 6 had been destroyed by fire. Thus they preserved in-situ organic evidence of human activities otherwise undetectable in the archaeological record. The architectural, artifactual, and archaeobotanical (seed/fruit and wood charcoal macroremains) evidence from these buildings is examined here together in an integrated manner in order to reveal different ways of interaction between people and the natural environment in Dikili Tash toward the end of the fifth millennium B.C. Among the issues discussed here is plant exploitation for various purposes, such as food, fuel, construction, and crafts, as well as specific archaeological contexts through which such activities can be discerned.
\end{abstract}

\section{Keywords}

Northern Greece, Southeastern Europe, Neolithic, crops, wild plant resources, anthracology

The tell site of Dikili Tash is located in the southeastern part of the Drama Plain, in eastern Macedonia, northern Greece. It lies some $2.5 \mathrm{~km}$ east of the ancient city of Philippi, on the outskirts of the modern town of Krinides in the district of Kavala (Figure 1). ${ }^{1}$ It is the biggest tell in the region and one of the largest in the Balkans, with its highest point standing at ca. $15 \mathrm{~m}$ above the modern ground (71 masl) and extending over 4.5 ha ( $250 \times 180 \mathrm{~m}$ at its base). An important freshwater spring lies immediately to the northeast of the tell. The water forms a small pond there, which is further drained by a small river running today along the east side of the tell (Figure 2). To the south stretched the big swamp that occupied the lowest parts of the Drama-Philippi Plain until 1931.

The site has been systematically excavated by the Archaeological Society at Athens and the French School at Athens since 1961 (Figure 3, on Color Plate I). Two successive research programs were carried out between 1961 and 2001. ${ }^{2}$ These programs revealed part of the site's long stratigraphical sequence from the Late Neolithic (LN) I period to the Late Bronze Age (ca. 5300-1200 cal B.C.) and brought to light substantial architectural remains and all kinds of artifacts from several periods, most remarkably the Neolithic (Darcque et al. 2007; Koukouli-Chryssanthaki et al. 1997; KoukouliChryssanthaki and Romiopoulou 1992; KoukouliChryssanthaki and Treuil 2008; Treuil 1992, 2004, in press). A third program started in $2008^{3}$ with the aim of fully reconstructing the history of the tell from the earliest occupation until today (Darcque, Koukouli-Chryssanthaki, Malamidou, and Tsirtsoni 2009, 2011, 2013). Altogether, research at the site and in the surrounding Drama-Philippi plain in the last 50 years has revealed rich information (already presented elsewhere ${ }^{4}$ ) about the formation of the tell and the evolution of the landscape in the surrounding region (Darcque and Tsirtsoni 2010; Darcque et al. 2014; Glais et al. 2016; Lespez 2008; Lespez et al. 2000).

In fact, Dikili Tash is a multi-period tell site. As recent coring has revealed (Lespez et al. 2013), habitation began in the second half of the seventh millennium B.C. during the Early Neolithic, spanned the Neolithic and the Bronze Age, and continued during the Classical/Hellenistic, Roman, and Byzantine periods. Ample information from excavations exists for the LN II phase. In particular, open excavation of Sector 6, which covers over $350 \mathrm{~m}^{2}$, allowed for the 


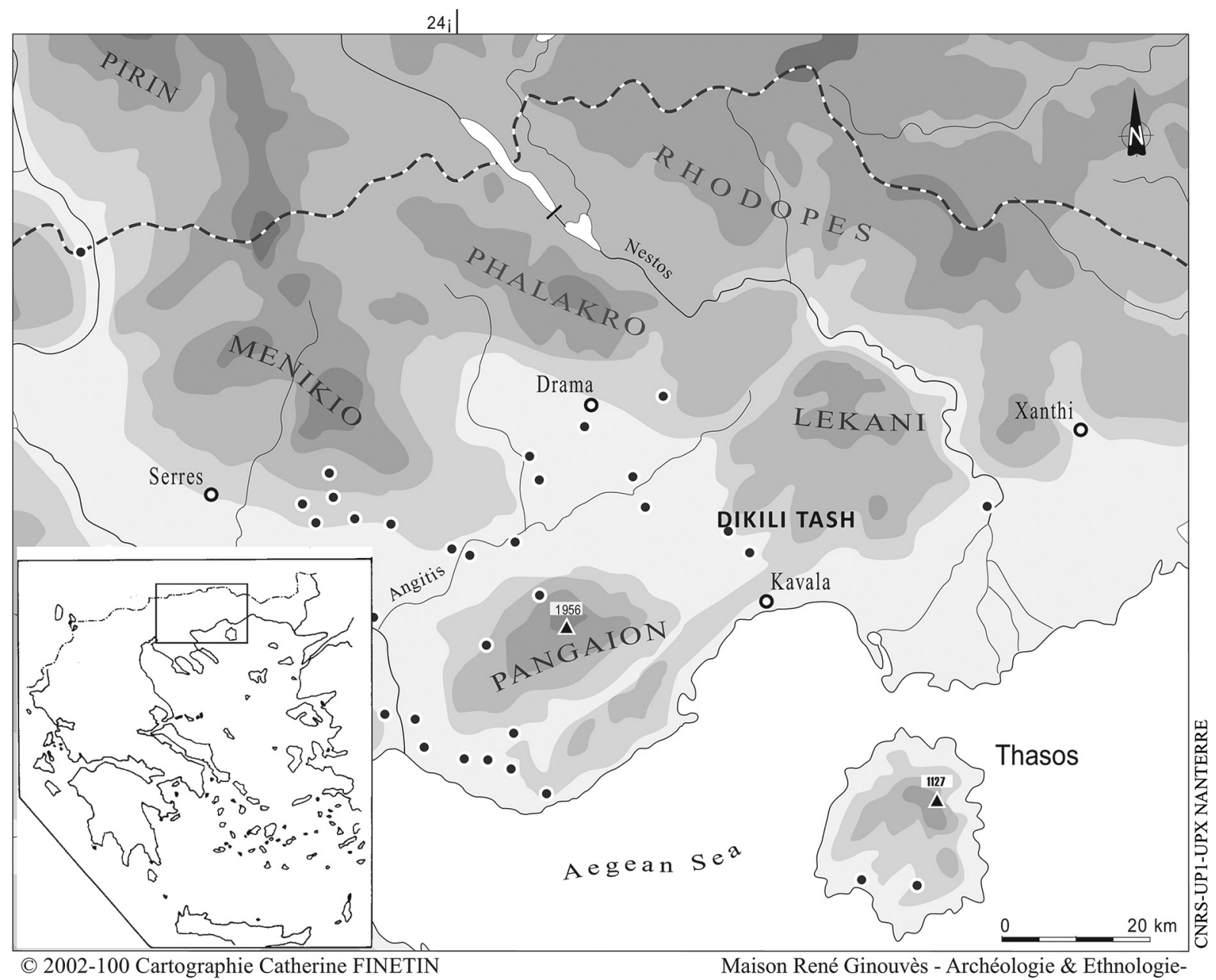

Figure 1. Map showing the location of Dikili Tash in eastern Macedonia, Greece.

exploration of the spatial arrangement and household organization of the settlement in the years around 4300-4200 cal B.C. ${ }^{5}$ (Figure 4; Darcque, KoukouliChryssanthaki, Malamidou, Treuil, and Tsirtsoni2011; Koukouli-Chryssanthaki et al. 1997).

\section{The Architectural and Artifactual Evidence}

Four Neolithic buildings have been unearthed in Sector 6 . They were all destroyed by fire - probably not all together in a single fire-around 4300-4200 cal B.C., during the LN II period. Their date is well established from the radiocarbon dating of the destruction layer (Darcque, Koukouli-Chryssanthaki, Malamidou, Treuil, and Tsirtsoni 2011:198-199, Figure 13; Koukouli-Chryssanthaki et al. 1997:694, Figure 7; Maniatis et al. 2014) and a series of thermoluminescence measurements, with results matching the ${ }^{14} \mathrm{C}$ dates of the same contexts (Roque et al. 2002). The Neolithic buildings were found under an Early Bronze Age occupation level dated by radiocarbon to around $3200 \mathrm{cal} \mathrm{B.C.} \mathrm{(Tsirtsoni} \mathrm{2016).}$
All four buildings (Buildings 1, 2, 3, and 4, from west to east) were rectangular, built in parallel rows along the northeast-southwest axis on slightly different levels on the eastern slope of the tell. Building 1, the westernmost of the four buildings, is about $7 \mathrm{~m}$ wide and more than $11 \mathrm{~m}$ long. There is no clear evidence for internal walls separating different rooms (Figure 5) (Darcque et al. 2013; Koukouli-Chryssanthaki et al. 1993; Koukouli-Chryssanthaki and Treuil 1989). Buildings 2 and 3 are less well preserved. The western limit of Building 2 is defined by a clear line of twinned postholes, whereas its total length and width have not been determined (Koukouli-Chryssanthaki et al. 1993:139; Koukouli-Chryssanthaki and Treuil 1989).

Building 3 measures $9 \times 5 \mathrm{~m}$ and has no traces of internal walls (Figure 6; Koukouli-Chryssanthaki 1996; Koukouli-Chryssanthaki et al. 1993:141). Building 4 is the best preserved of the four buildings. It has a preserved length of $11 \mathrm{~m}$ and a width of $6 \mathrm{~m}$ (Figure 7) (Darcque et al. 2007; Koukouli-Chryssanthaki 1994, 1995; Koukouli-Chryssanthaki et al. 1997). The building was divided into three spaces (Rooms A, 


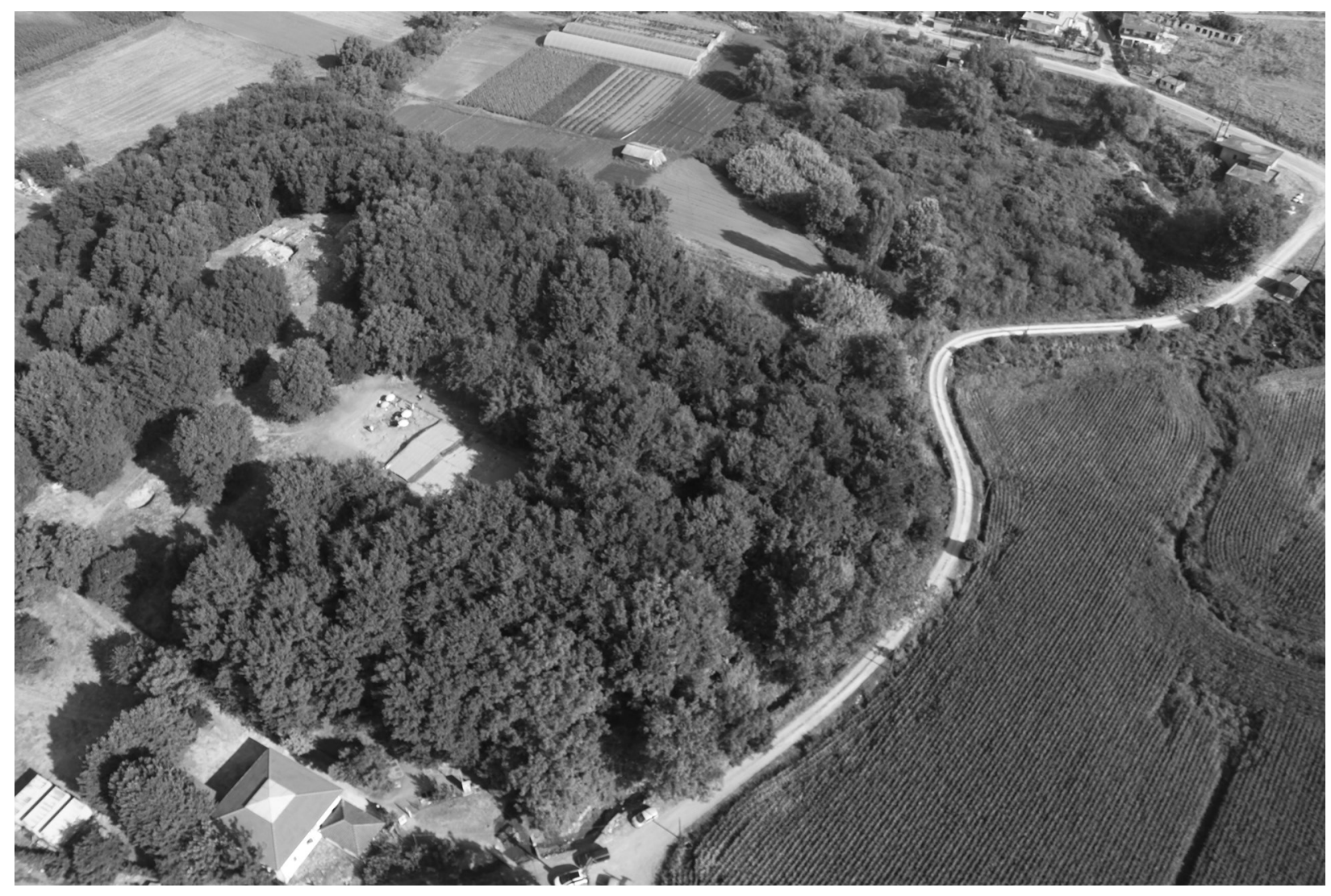

Figure 2. Aerial view of the tell from the southeast with the main excavation sectors visible. A water source and pond can be seen to the northeast.

$\mathrm{B}$, and $\mathrm{C}$, from north to south) by internal walls. Room $\mathrm{C}$ is only partly preserved since its southern part has fallen down the tell's slope. Each space has its own entrance on the southeastern long side and an oven, which is close to the wall opposite the entrance, with its opening turned toward the entrance. The ovens are domed with a rectangular ground plan with round corners and a protruding surface before the opening (Deshayes 1974:72). Next to the ovens, rectangular sink-like clay constructions or platforms completed the "kitchen equipment," whereas Room A in Building 4 also included a semicircular earthen bench in contact with the southeast wall (Figure 8). Two similar ovens were found in the western part of Building 1 (see Figure 5, loci 6-114 and 6-015), the south of which (locus 6-015) is better preserved. A double-headed zoomorphic figurine was still standing on its floor (Figure 9). Similar objects are known to date from Dikili Tash and neighboring sites, but were never found in primary contexts (Gimbutas 1986:255, Figures LVI:2, LVIII:3, LXIII:4; Marangou 1992:15, Figures 78a and 78d). A grindstone and abundant charred pulses were found on a platform next to the oven (see Figure 5, locus 6-044, and Figure 10). A hearth or oven occupies the center of the northern part of Building 3, while remains from the substructure of a hearth or oven were found in Building 2 (see Figure 4). No indication of an entrance was found in Buildings 2 and 3. Judging from a wall fragment (see Figure 6), which probably was part of a door frame (locus 6-026; see Figure 11) on the axis of the oven (locus 6-015), the entrance of Building 1 would have been located in its eastern long wall.

Each building was equipped with cooking and storage facilities. Each space of Building 4 contained at least three or four big storage bins made of raw clay tempered with rich vegetal material (straw) and decorated with simple grooves (Figure 8). A big jar with incised decoration was uncovered in the southern part of Building 3 (Figure 12) (KoukouliChryssanthaki 1996; Koukouli-Chryssanthaki et al. 1993:141), while several big jars were collected from Building 1. Numerous vessels for food preparation and consumption; grindstones; tools from stone, clay, bone, or antler; ornaments (beads, pendants); clay figurines; and other small objects were lying on the floor of the buildings at the time of destruction.

The equivalent dimensions of the spaces, the re- 


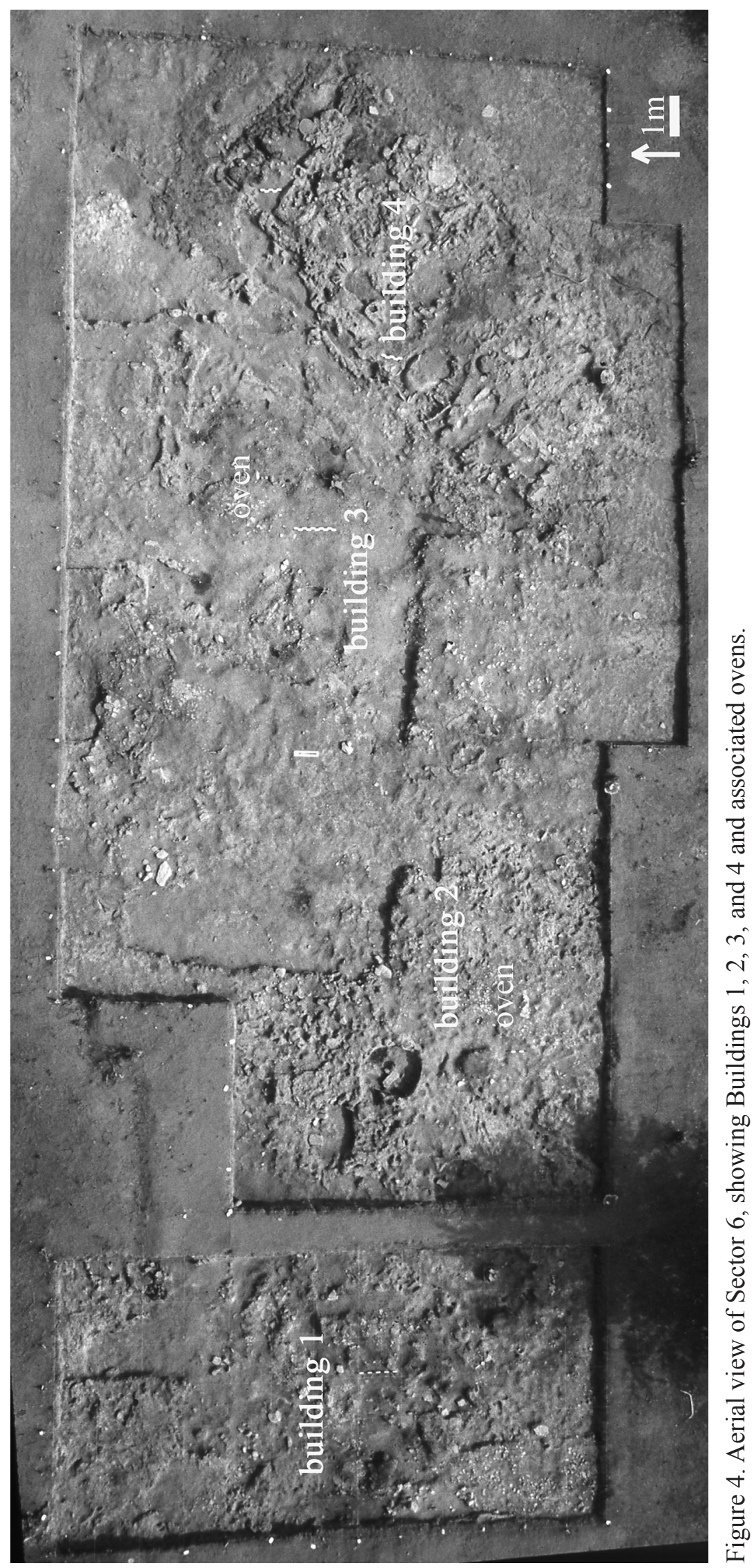


semblances of their internal structure and equipment, and the fact that they had separate entrances with no communication between them, leads to the conclusion that they accommodated independent households. The relatively small dimensions of the rooms suggest that they were used by a limited number of individuals, very likely a nuclear family.
Areas of grey soil containing sherds and bones that were found between and around the buildings have been identified as outdoor spaces, such as streets or courtyards. The destruction layer inside the buildings included a large number of wattle and daub fragments, which had collapsed from the walls and roofs. The destruction by fire helped to preserve in situ, either

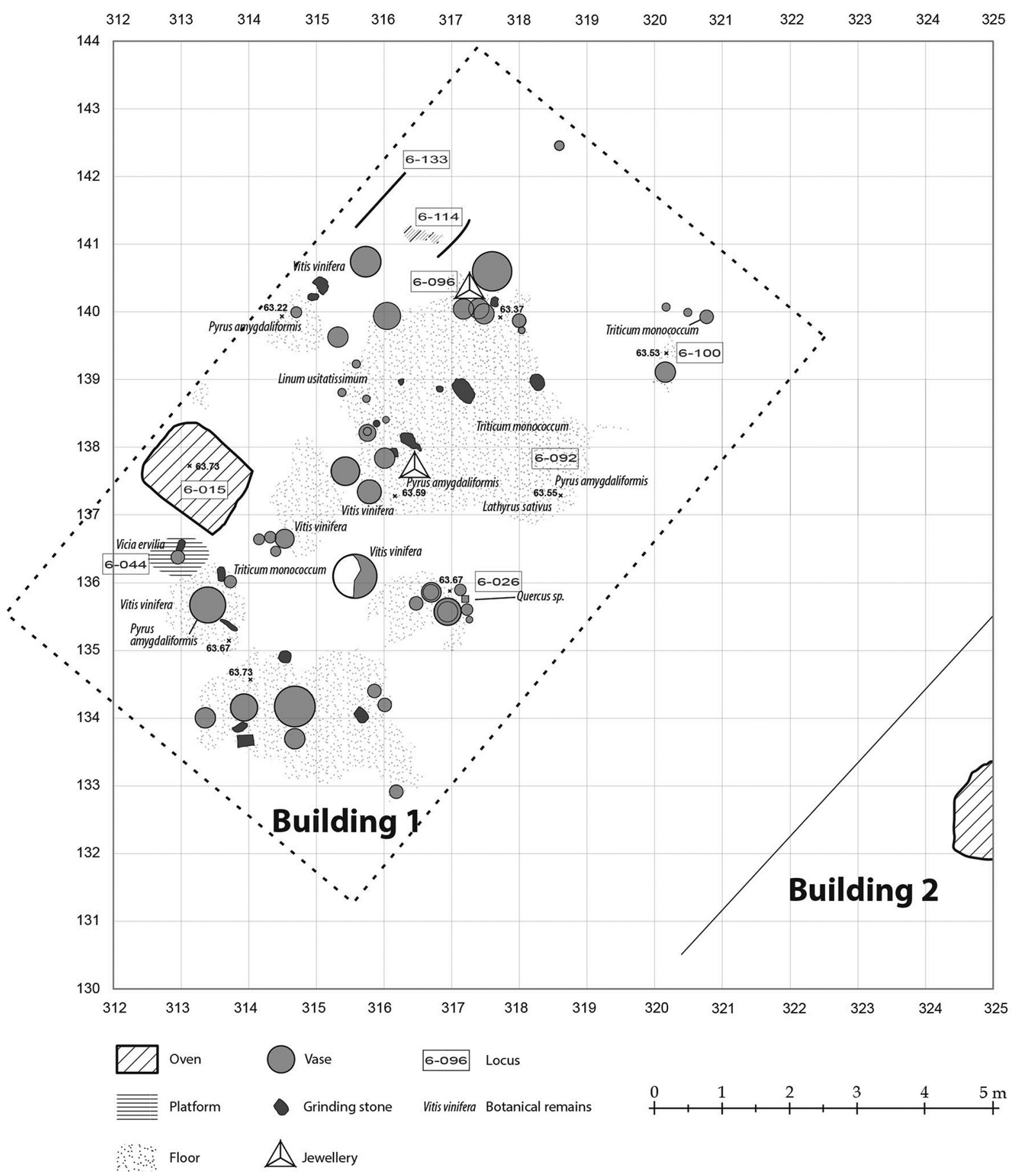

Figure 5. Ground plan of Building 1 


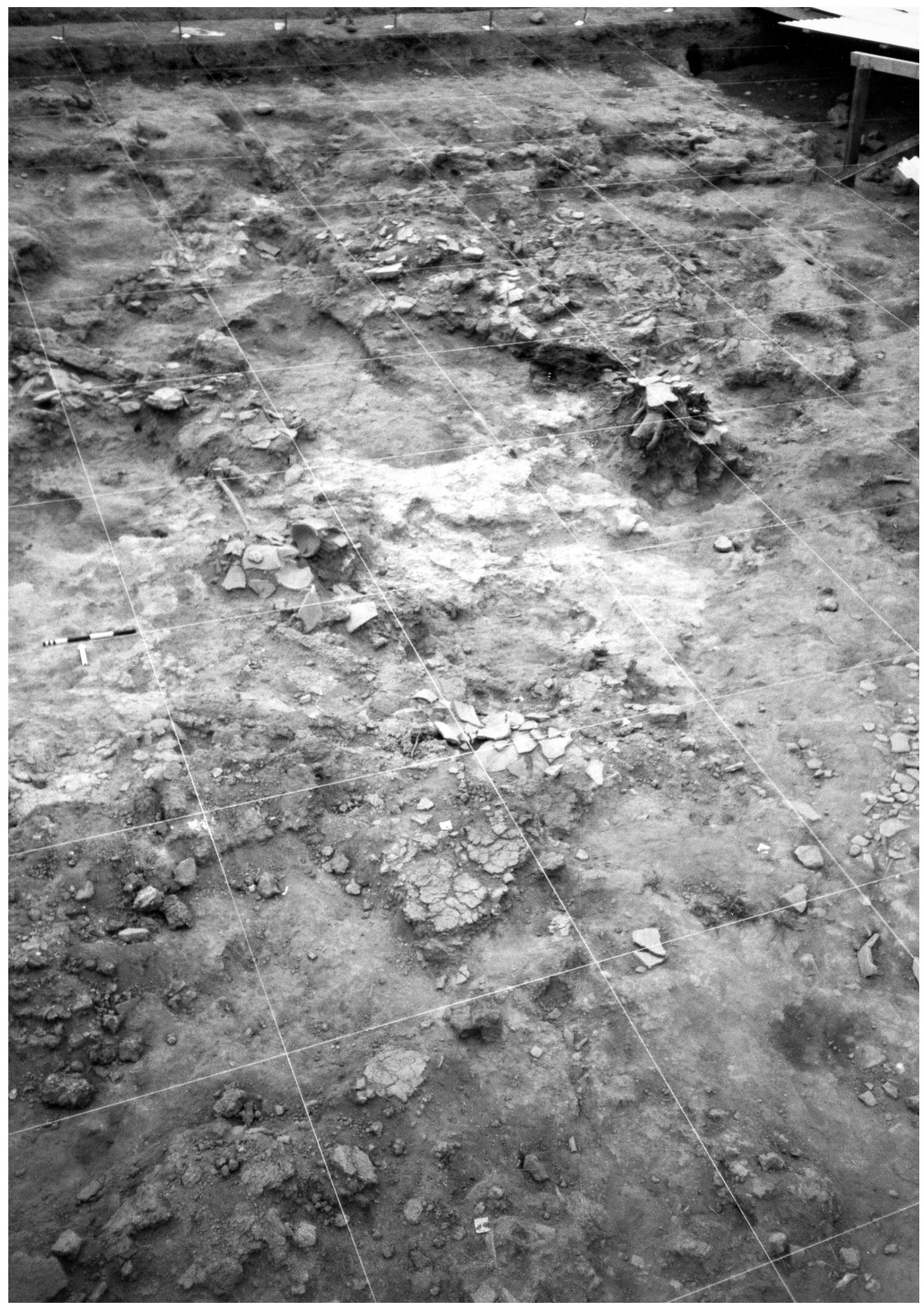

Figure 6. General view of Building 3. 
inside or outside the buildings, plenty of charred organic material, which points to the exploitation of a wide variety of plant resources by the occupants of the buildings.

\section{Vegetal Imprints}

Careful collection of the raw clay debris hardened by fire has allowed the study of the imprints of wood and vegetal material used for building and construction (posts, planks, tree branches, reeds, straw, chaff, etc.; see Figure 13). The wide range of wood imprints, which has been recorded during the ongoing study, shows a great deal of know-how and woodworking skills necessary to construct substantial buildings (Germain-Vallée et al. 2011; Martinez 2001; Marti- nez and Prévost-Dermarkar 2003; Papadopoulou and Prévost-Dermarkar 2007; Prévost-Dermarkar 2002). House walls were built with posts connected by wattle or joined posts connected with tied-up sticks. The imprints of posts appear to be both round and angular. The angular imprints on many wall fragments suggest the use of split timber. For instance, the walls of Building 4 were constructed out of upright wooden posts, which were placed one next to another and set into foundation trenches. Furthermore, lumps of architectural clay material with vegetal imprints suggest the use of vegetal materials for tempering clayish soil to construct walls, roofs, floors, ovens, storage bins, and so on. Temper (earthen mineral or organic) was necessary in order to prevent the earthen material from cracking during the drying procedure. Chopped straw

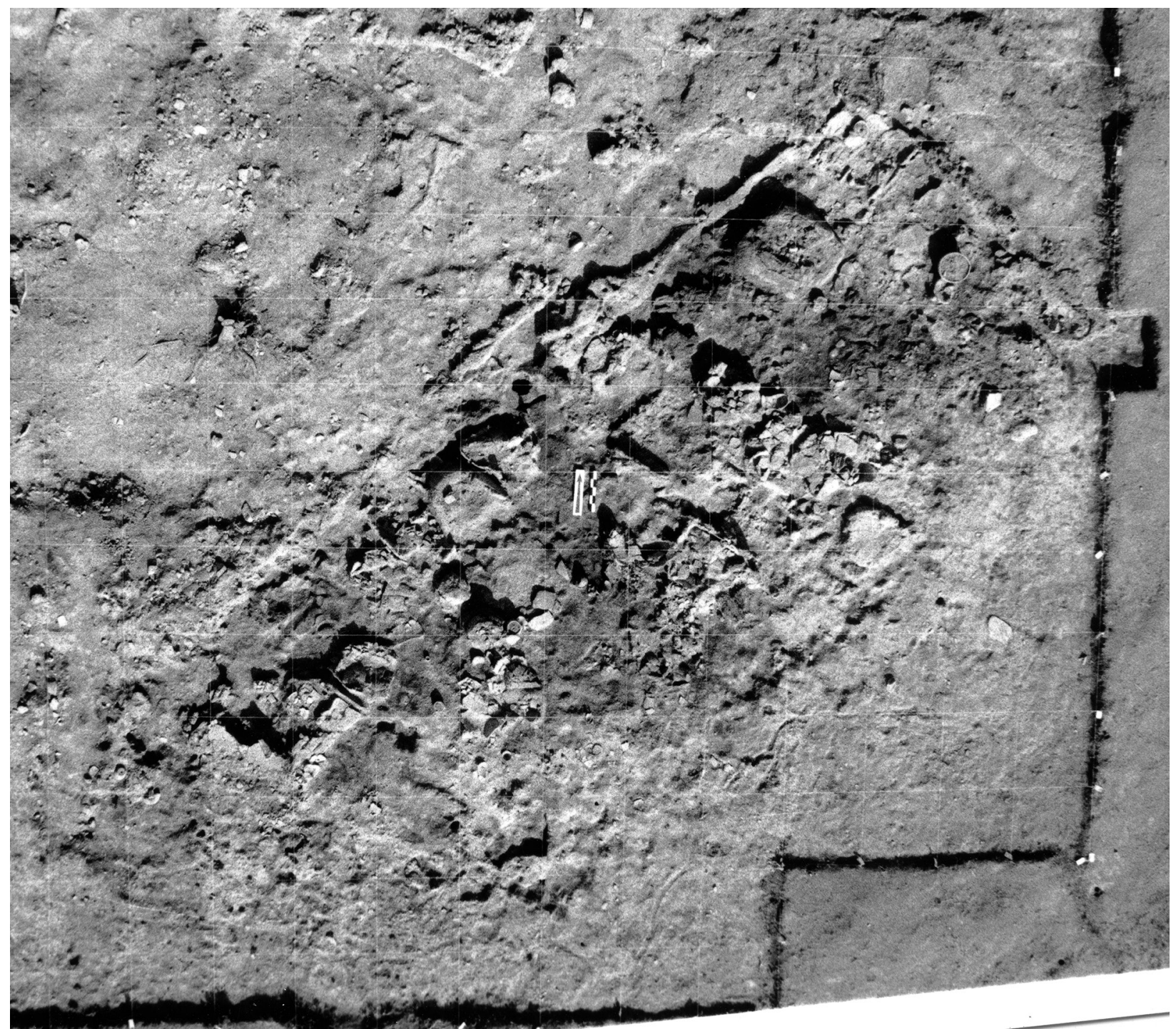

Figure 7. Aerial view of Building 4. 


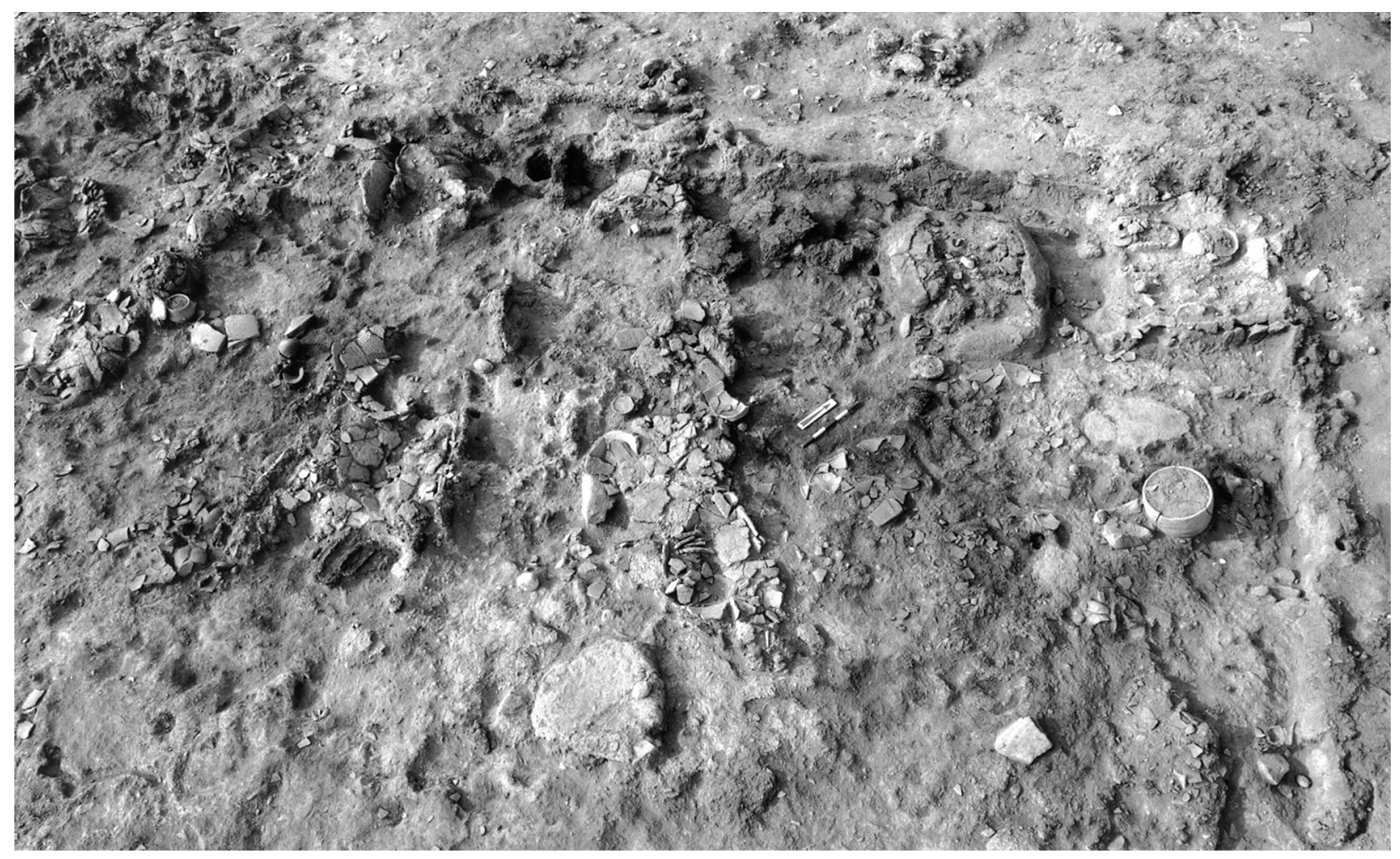

Figure 8. Interior of Room A, Building 4

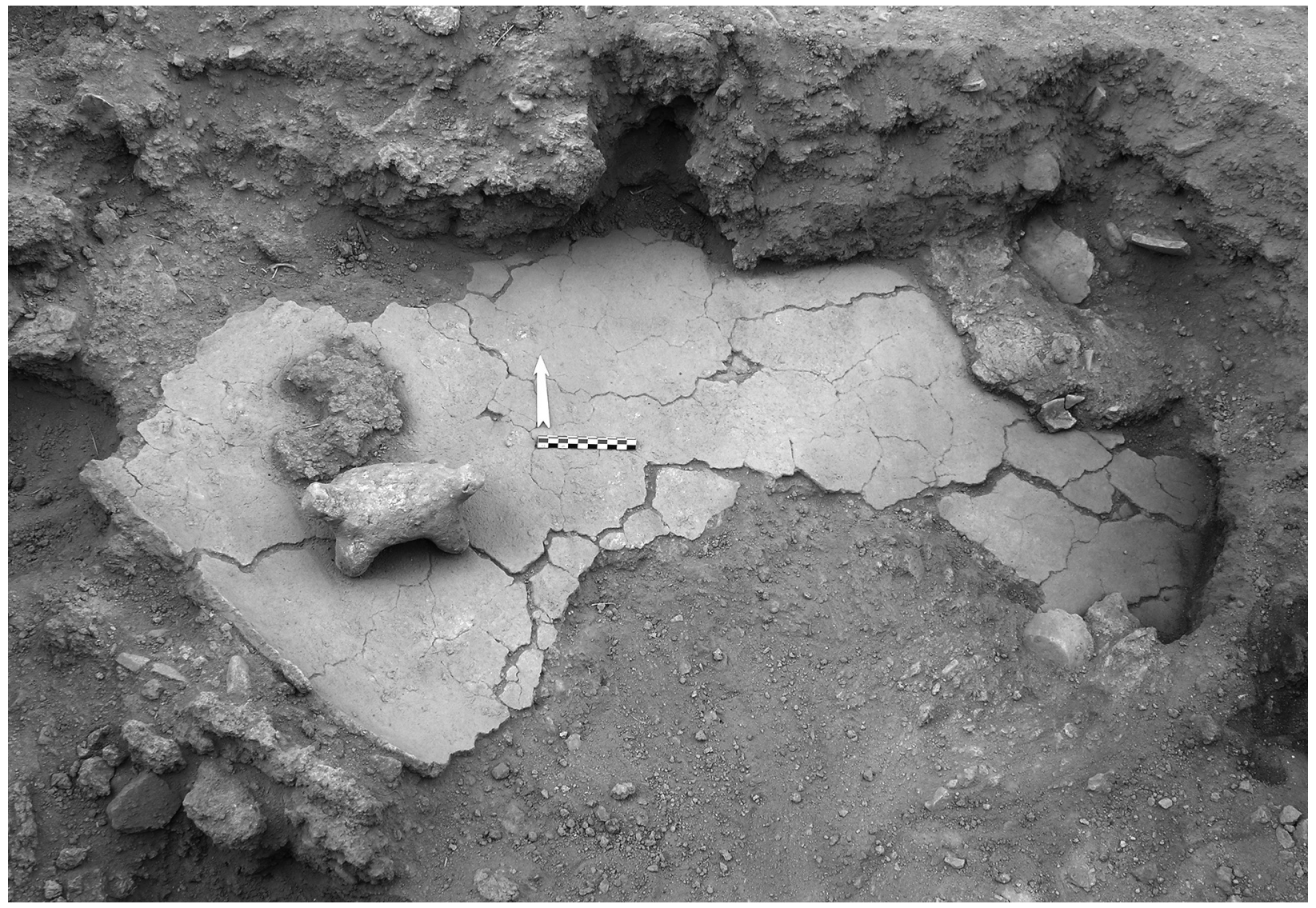

Figure 9. Building 1, floor of oven 6-015 with two-headed animal figurine in situ. 


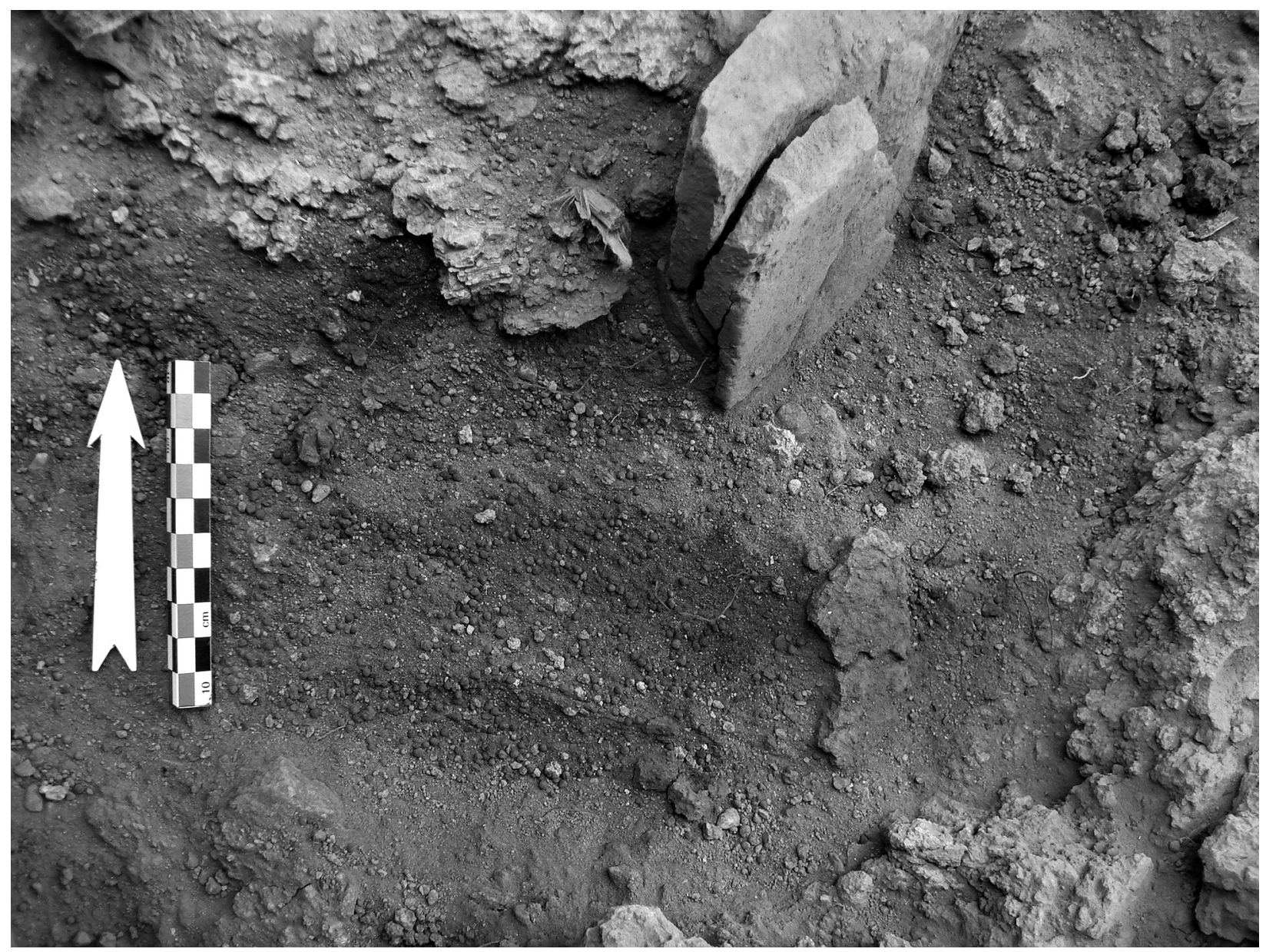

Figure 10. Seeds of Vicia ervilia in Building 1, Dikili Tash 2010 excavation season.

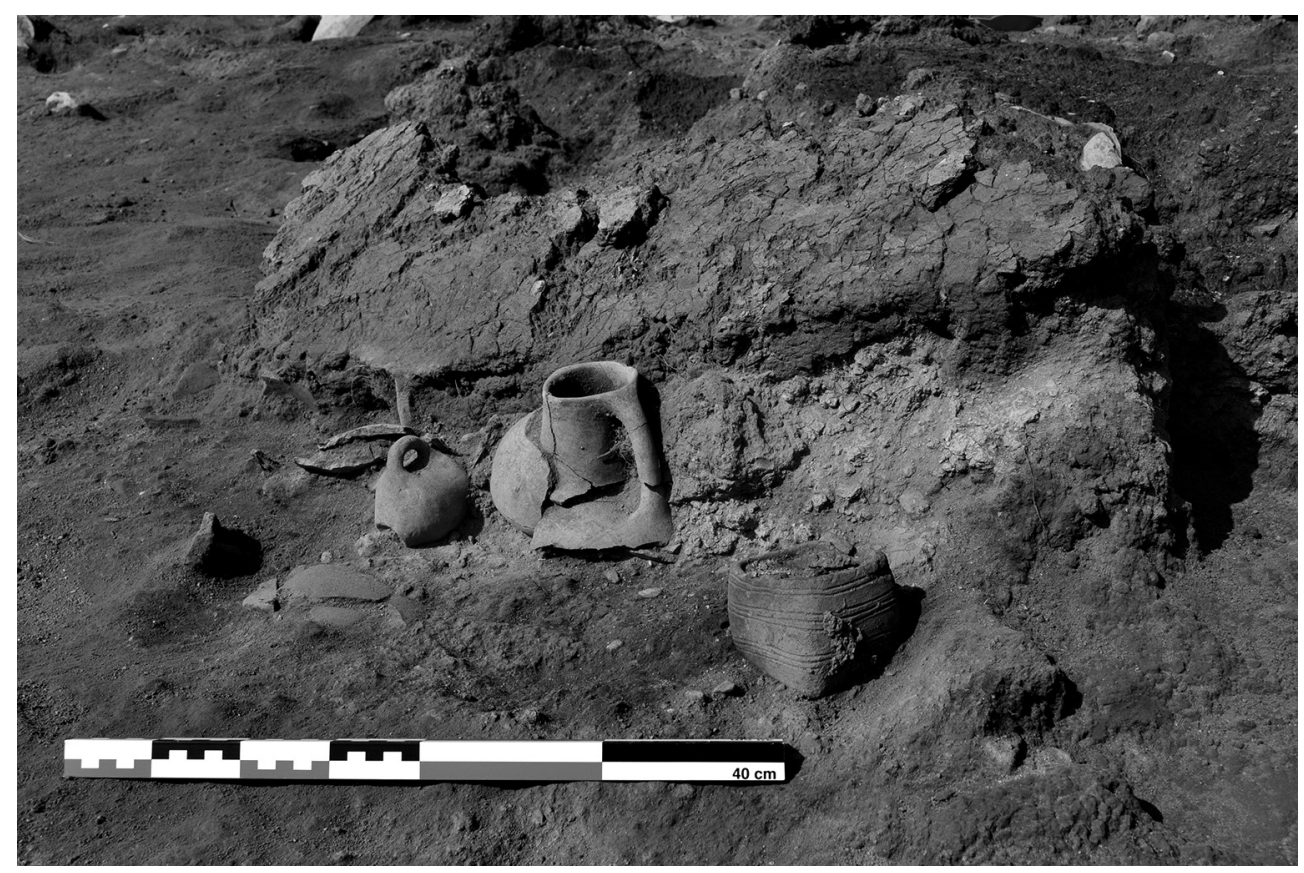

Figure 11. Building 1, fallen part of a wall possibly from a door frame and ceramic vessels in situ. 


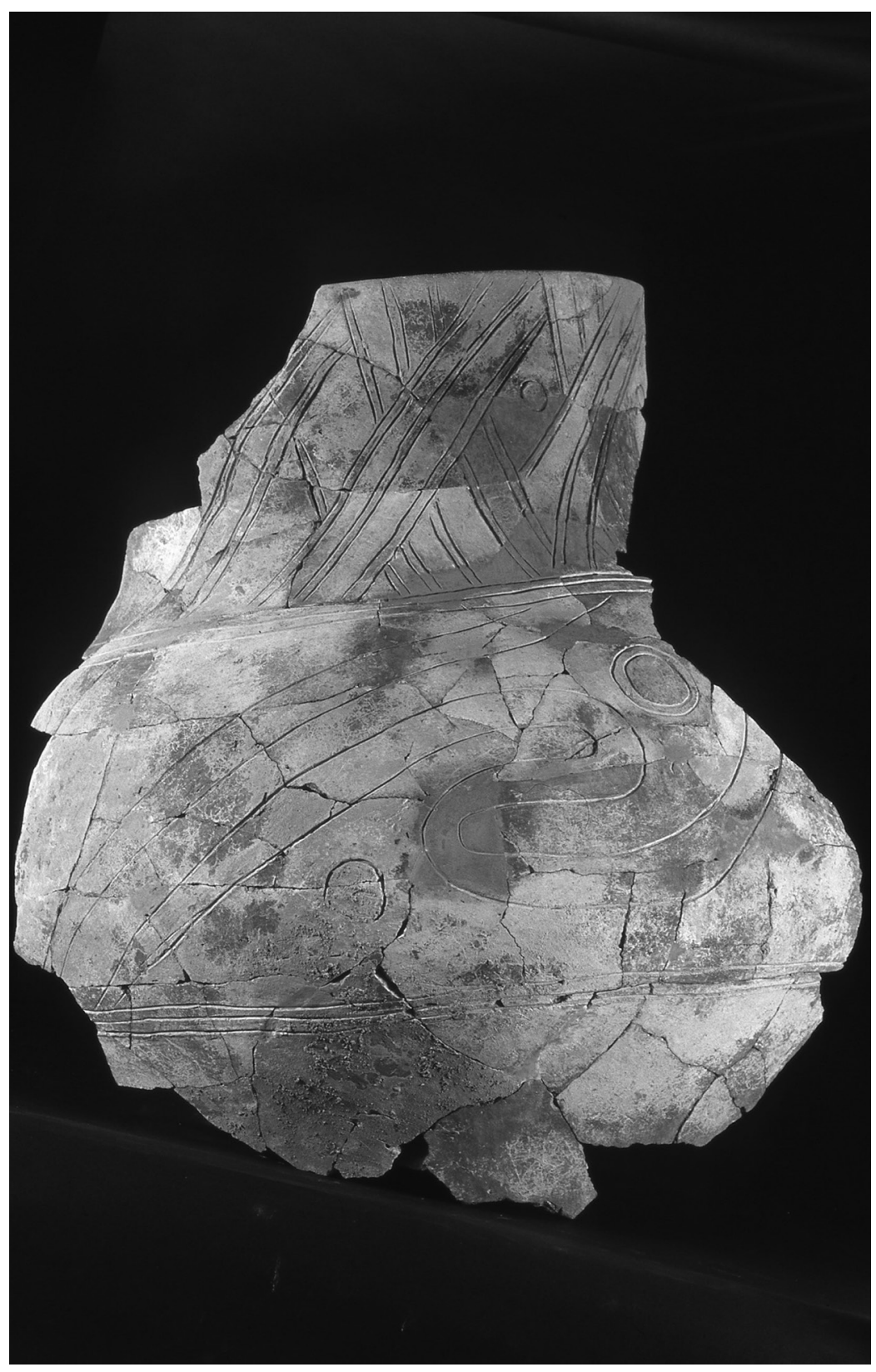

Figure 12. Jar with incised decoration from Building 3 (height $74 \mathrm{~cm}$ ).

and chaff were the most frequent vegetable temper used for construction earth during the LN II. Different fabrics of earthen material have been identified. Quantities and types of vegetable temper varied from one fabric to another. It seems that the choices were directly related to the intended use of each fabric (i.e. different material for walls, oven vaults, etc.).

Mat impressions on vessel bottoms are common indirect evidence for the use of plant fibers in carpet making, basketwork, or wickerwork. In one case, within Building 1, we witnessed the charred remains of mats on the floor, while in other cases we were able to guess the existence of containers probably made of wood from the form of the concentrations of objects. A burned clod of earth bearing the imprints of interwoven twines, found in Sector 1, has been identified as indirect evidence of a carrying net made of plant fibers containing clay material (Martinez 2004).

We are expecting more results from the ongoing study of this kind of finds with recently developed methods for identifying archaeological plant fiber sources (Borojevic and Mountain 2013; Gärtner et al. 2014). 


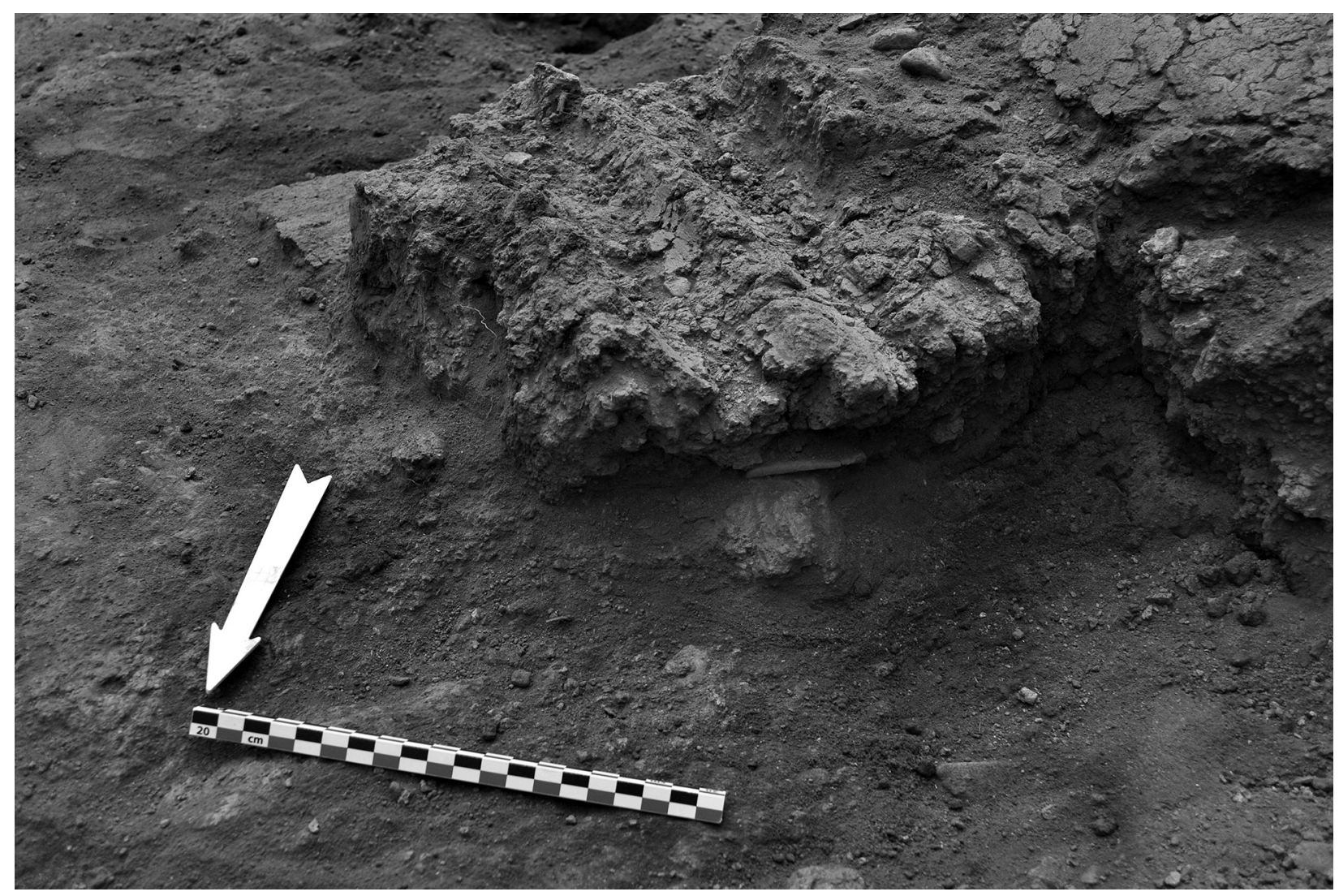

Figure 13. Clay fragments with imprints of wood lying on the floor of Building 1.

\section{The Archaeobotanical Evidence}

All contexts of the burned buildings in Sector 6 yielded a rich inventory of wood, stored crops, and wild harvests in a very good state of charred preservation (Figure 14). The excavation and find-collection techniques were adapted to the specificities of this kind of find. Thus, special attention was given to the systematic collection and water sieving of sediments in order to retrieve a maximum number of archaeobotanical (seed/fruit and wood charcoal macroremains) data in context. Due to the intensive sampling, retrieved charred remains were abundant and offered rich direct evidence for the use of wood and crops. Some of the charred wood remains may have come from firewood (cooking, heating, pyrotechnology), while others, apart from construction, witness the presence of objects that could not survive, such as containers, tool handles, furniture, and so on.

\section{Wood Charcoal and Woodland Management}

It should be stressed that only part of the material is considered here, since the study of finds from the 2008-2013 campaigns is in progress. The wood charcoal material discussed here comes from 84 water flotation samples, 25 of which were recovered from areas outside the buildings, and 59 from the destruction layer inside the buildings. On the one hand, the wood charcoal material that was scattered in the open areas around the buildings may be explained as discarded firewood remains from domestic hearths or ovens. As such, it has a palaeoecological value and may provide information about the vegetation of the areas used for the procurement of fuel. On the other hand, the material from the interior of the four LN II buildings may provide ethnobotanical information regarding mainly the selection of plant species for construction purposes, as well as the technological aspects of construction.

\section{Flora and Vegetation Types}

The presence and distribution of the taxa in outside spaces and inside the four buildings are shown in Figure 15. Deciduous woodland is represented by deciduous oak, ash, oriental hornbeam/hornbeam, and maple, while the undergrowth of such woodland and its more open borders would have included cornelian cherry/dogwood, hazel, small trees of the wild pear and plum families, juniper, and the wayfaring tree. Sun-loving, open vegetation would have grown near 


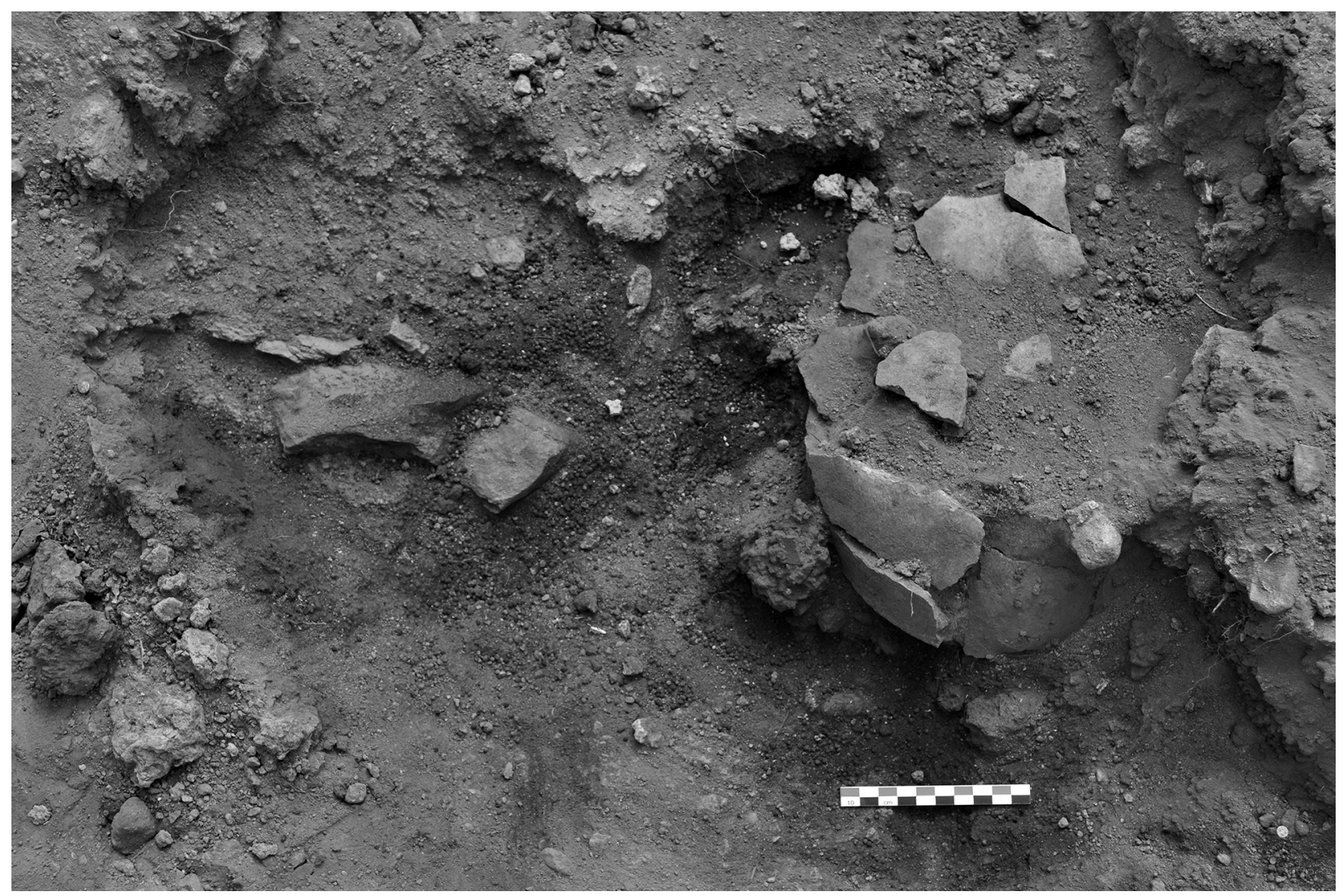

Figure 14. Concentration of carbonized seeds and associated ceramic vessel on the floor of Building 1.

the site and probably next to the deciduous forests and would have included terebinth, Christ's thorn, and shrubs of the pulse family, along with several evergreen trees such as mock privet, strawberry tree, and evergreen oak. Mountain conifers such as black pine would have grown at higher altitudes on the mountains to the west and north of the basin. Finally, riparian vegetation with softwoods (willow/poplar), hardwoods (alder, oriental plane, elm, ash), and climbers (vine) would have been growing in the nearby wetlands and flood plain.

\section{Firewood}

The results from the exterior areas show that deciduous oak is by far the best represented taxon in the LN II assemblage, followed by ash. The remaining taxa are represented in very small numbers (Table 1 ). Grouped in the vegetation types previously defined, all other trees of deciduous woodland, excluding deciduous oak, total 5.4 percent. Similarly, the wetland taxa excluding ash account for only 3.5 percent of the LN II assemblage from Sector 6, while undergrowth and evergreens have similar proportions around 6 percent. Mountain conifers are hardly present (.2 percent).
The proportions of deciduous oak (53.9 percent) suggest that these were the most abundant trees in the LN deciduous woodland, while other deciduous trees played a secondary role. This suggestion is in agreement with the dominant role of deciduous oak in the pollen record of northern Greece for the Early to Middle Holocene (Bottema 1974; Turner and Greig 1986; Wijmstra 1969), with other wood charcoal studies carried out in Neolithic sites in northern Greece (Karkanas et al. 2011; Ntinou 2002, 2010, 2014) and with the present-day extension of deciduous oak woodlands that constitute the main forest cover.

Narrow-leafed ash would have been abundant in the wetland areas, as well as manna ash in the oak woods. Vegetation of woodland borders and open vegetation could have expanded as a result of the natural thinning of the forests toward their edges, or as a result of anthropogenic clearings in order to open cultivation plots and paths for access to resources.

\section{Construction Wood (Timber)}

Flotation samples from the burnt destruction layer of the four LN II buildings showed the presence of many taxa (Figure 16). The frequency of occurrence bar chart shows that deciduous oak was by far 


\begin{tabular}{|c|c|c|c|c|c|c|c|c|}
\hline \multirow[b]{2}{*}{ Taxa } & \multicolumn{8}{|c|}{ LATE NEOLITHIC II } \\
\hline & \multicolumn{4}{|c|}{\begin{tabular}{l|l} 
Exteriors &
\end{tabular}} & & \multicolumn{3}{|c|}{ Buildings } \\
\hline \multicolumn{9}{|l|}{ Pinus nigra } \\
\hline \multicolumn{9}{|c|}{ Quercus sp. deciduous } \\
\hline \multicolumn{9}{|c|}{ Quercus sp. } \\
\hline \multicolumn{9}{|l|}{ Carpinus orientalis } \\
\hline \multicolumn{9}{|l|}{ Carpinus sp. } \\
\hline \multicolumn{9}{|l|}{ Acer sp. } \\
\hline \multicolumn{9}{|l|}{ Corylus avellana } \\
\hline \multicolumn{9}{|l|}{ Maloideae } \\
\hline \multicolumn{9}{|l|}{ cf. Maloideae } \\
\hline \multicolumn{9}{|l|}{ Cornus sp. } \\
\hline \multicolumn{9}{|l|}{ Viburnum sp. } \\
\hline \multicolumn{9}{|l|}{ Cornus/Viburnum } \\
\hline \multicolumn{9}{|l|}{ Juniperus sp. } \\
\hline \multicolumn{9}{|l|}{ Prunus sp. } \\
\hline \multicolumn{9}{|c|}{ Paliurus spina-christi } \\
\hline \multicolumn{9}{|c|}{ Clematis sp. } \\
\hline \multicolumn{9}{|l|}{ Pistacia terebinthus } \\
\hline \multicolumn{9}{|l|}{ Leguminosae } \\
\hline \multicolumn{9}{|l|}{ Ficus carica } \\
\hline \multicolumn{9}{|c|}{ Phillyrea/Rhamnus alaternus } \\
\hline \multicolumn{9}{|c|}{ Quercus sp. evergreen } \\
\hline \multicolumn{9}{|l|}{ Arbutus sp. } \\
\hline \multicolumn{9}{|c|}{ cf. Cupressus sempervirens } \\
\hline Fraxinus sp. & 11 & 1 & 111 & 1 & & 1 & 1 & 11 \\
\hline Ulmus sp. & 11 & 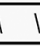 & $\begin{array}{lll}11 & 1 \\
\end{array}$ & 1 & & 1 & 1 & 11 \\
\hline Alnus sp. & 11 & 1 & $\begin{array}{lll}1 & 1 \\
\end{array}$ & 1 & & 1 & 1 & 11 \\
\hline Salix/Populus & 11 & 1 & 111 & 1 & & & & \\
\hline Platanus orientalis & & & & & & 1 & 1 & 11 \\
\hline Vitis vinifera & 11 & 11 & $\begin{array}{lll}11 & 1 \\
\end{array}$ & 1 & & & & \\
\hline Monocotyledon & 11 & 1 & $\begin{array}{lll}11 & 1\end{array}$ & 1 & & & & \\
\hline
\end{tabular}

the most frequently used timber in each one of the buildings (ca. 60-100 percent), followed by ash (ca. 30-60 percent) and to a lesser degree by hornbeam (ca. 10-50 percent) and juniper (ca. 15-50 percent). Hazel, wayfaring/cornelian cherry/dogwood were ubiquitous in all buildings (ca. 5-25 percent).

\section{Plant Food Procurement}

The Neolithic buildings in Sector 6 yielded a rich inventory of stored crops and harvests from the wild. Substantial quantities of charred grains, pulses, and fruits were collected from several parts of the excavated area. More than 2,000 soil samples have been processed by flotation and examined for plant remains, 25 of which were fully studied after being selected on the basis of content, context, and richness (Valamoti 2015). The richer concentrations were found within Building 1. This may be attributed to a variety of reasons, such as differential sampling intensity, differential contents, or preservation conditions among the different houses. These alternatives are currently under investigation. Among the identified species

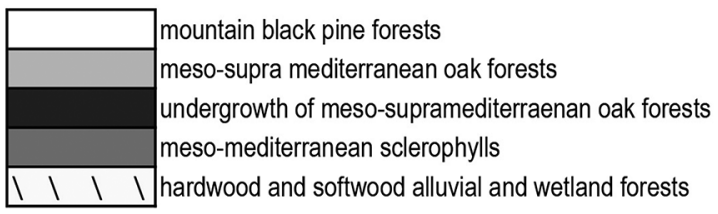

Figure 15. Presence of taxa in the exterior areas and buildings. The taxa are grouped in potential vegetation types indicated by different shading. (Courtesy M. Ntinou)

harvested from trees probably growing around the settlement are wild pears (cf. Pyrus amygdaliformis; Figure 17), acorns (Quercus sp.), figs (Ficus carica L.), blackberries (Rubus fruticosus L. agg.) and grape (Vitis vinifera). A rich variety of cultivated crops include pulses like bitter vetch (Vicia ervilia) and grass pea (Lathyrus sativus) and cereals such as einkorn (Triticum monococcum; Figure 18) and naked barley (Hordeum vulgare var. nudum). Other crops at the site were flax (Linum usitatissimum; Figure 19) and possibly lentil (Lens culinaris). The vast majority of crops appear largely clean of weed seeds.

The quantity and purity of their composition suggest that these were clean crops, which were stored inside the buildings or in some phase of processing (grinding, fermenting, or cooking). Some of these crops were associated with ceramic containers, while others were probably stored in perishable containers (for example, wood chests or cloth bags).

An impressive grape pip concentration, including grape pips and pressings (numbering more than 3,000 pips) was found in Building 1 in association with a ceramic vessel (Figure 20). It is possible that 
Table 1. Frequency of Taxa in the Wood Charcoal Assemblage from the LN II Exterior Areas.

\begin{tabular}{|c|c|c|}
\hline Taxa & Number of Fragments & $\begin{array}{l}\text { Percent of Total Fragments } \\
(\%)\end{array}$ \\
\hline Pinus nigra & 1 & .2 \\
\hline Quercus sp. deciduous & 241 & 53.9 \\
\hline Quercus sp. & 15 & 3.4 \\
\hline Carpinus orientalis & 3 & .7 \\
\hline Carpinus sp. & 5 & 1.1 \\
\hline Corylaceae & 1 & .2 \\
\hline Corylus avellana & 5 & 1.1 \\
\hline Maloideae & 4 & .9 \\
\hline cf. Maloideae & 1 & .2 \\
\hline Cornus sp. & 2 & .4 \\
\hline Viburnum sp. & 2 & .4 \\
\hline Juniperus sp. & 7 & 1.6 \\
\hline Clematis sp. & 1 & .2 \\
\hline Pistacia terebinthus & 2 & .4 \\
\hline Leguminosae & 3 & .7 \\
\hline cf. Leguminosae & 1 & .2 \\
\hline Ficus carica & 1 & .2 \\
\hline Phillyrea/Rhamnus alaternus & 18 & 4.0 \\
\hline Quercus sp. evergreen & 1 & .2 \\
\hline Arbutus sp. & 10 & 2.2 \\
\hline cf. Cupressus sempervirens & 1 & .2 \\
\hline Fraxinus sp. & 104 & 23.3 \\
\hline Ulmus sp. & 5 & 1.1 \\
\hline Ulmaceae & 3 & .7 \\
\hline Alnus sp. & 2 & .4 \\
\hline Salix/Populus & 4 & .9 \\
\hline Vitis vinifera & 1 & .2 \\
\hline Monocotyledon & 1 & .2 \\
\hline Angiosperm & 2 & .4 \\
\hline Total & 447 & 100 \\
\hline
\end{tabular}

the pips and pressings point to wine production. If this is the case, the fermentation of grape juice must have been underway when the house was destroyed by fire. A small number of grape pips and skins were reported from Building 3 as well (Valamoti 2004), suggesting that wine making may have been practiced by several households at the site, the earliest evidence to date for wine making in the Aegean and the Eastern Mediterranean (Garnier and Valamoti 2016; Valamoti2015; Valamoti et al. 2007). The grape pips have been identified as morphologically wild (Mangafa and Kotsakis 1996), yet their cultivation or early management cannot be excluded (Valamoti 2015; Valamoti et al. 2007, 2015). 


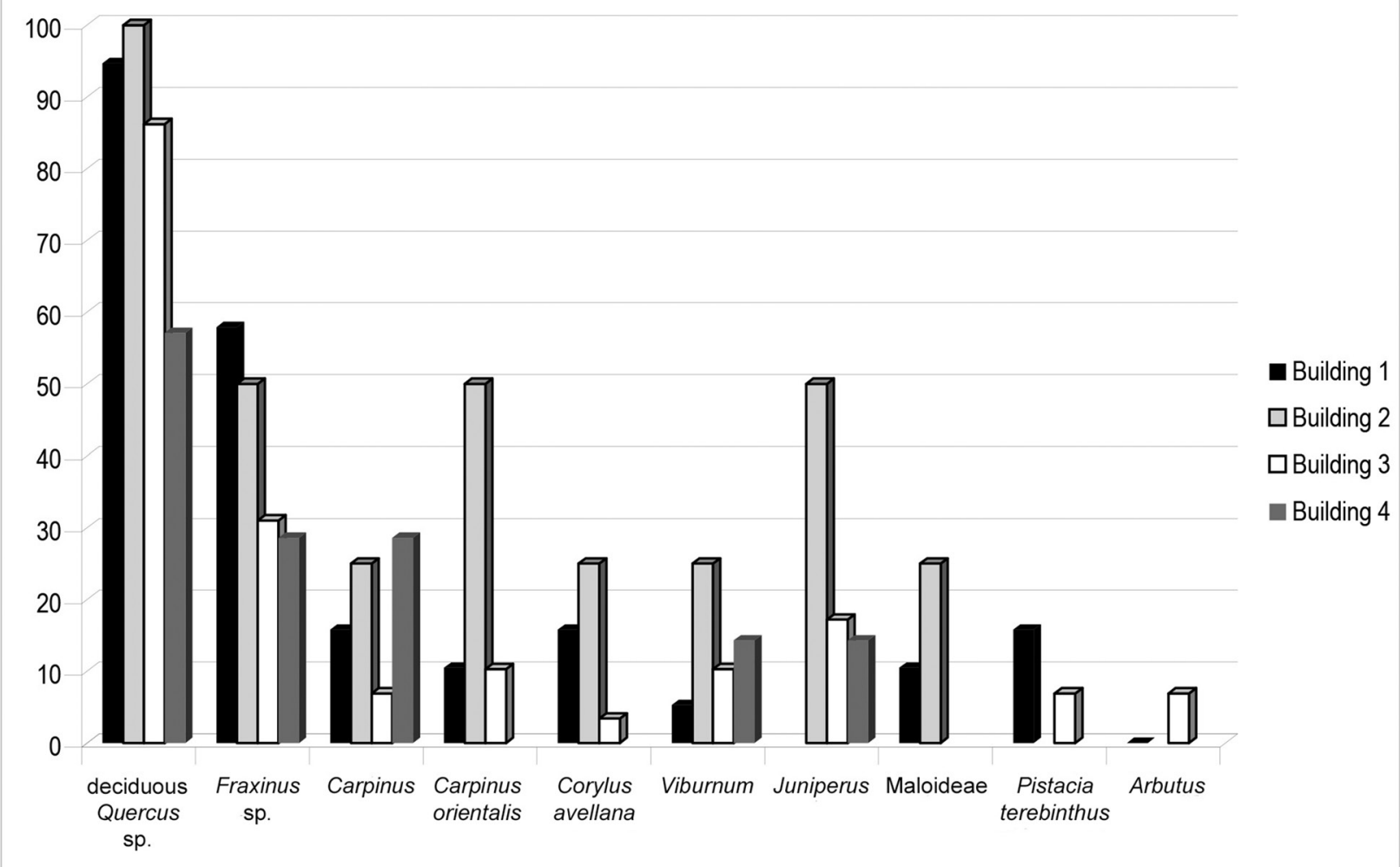

Figure 16. Bar chart showing the frequency of occurrence of taxa in the samples of each of the four buildings. (Courtesy M. Ntinou)

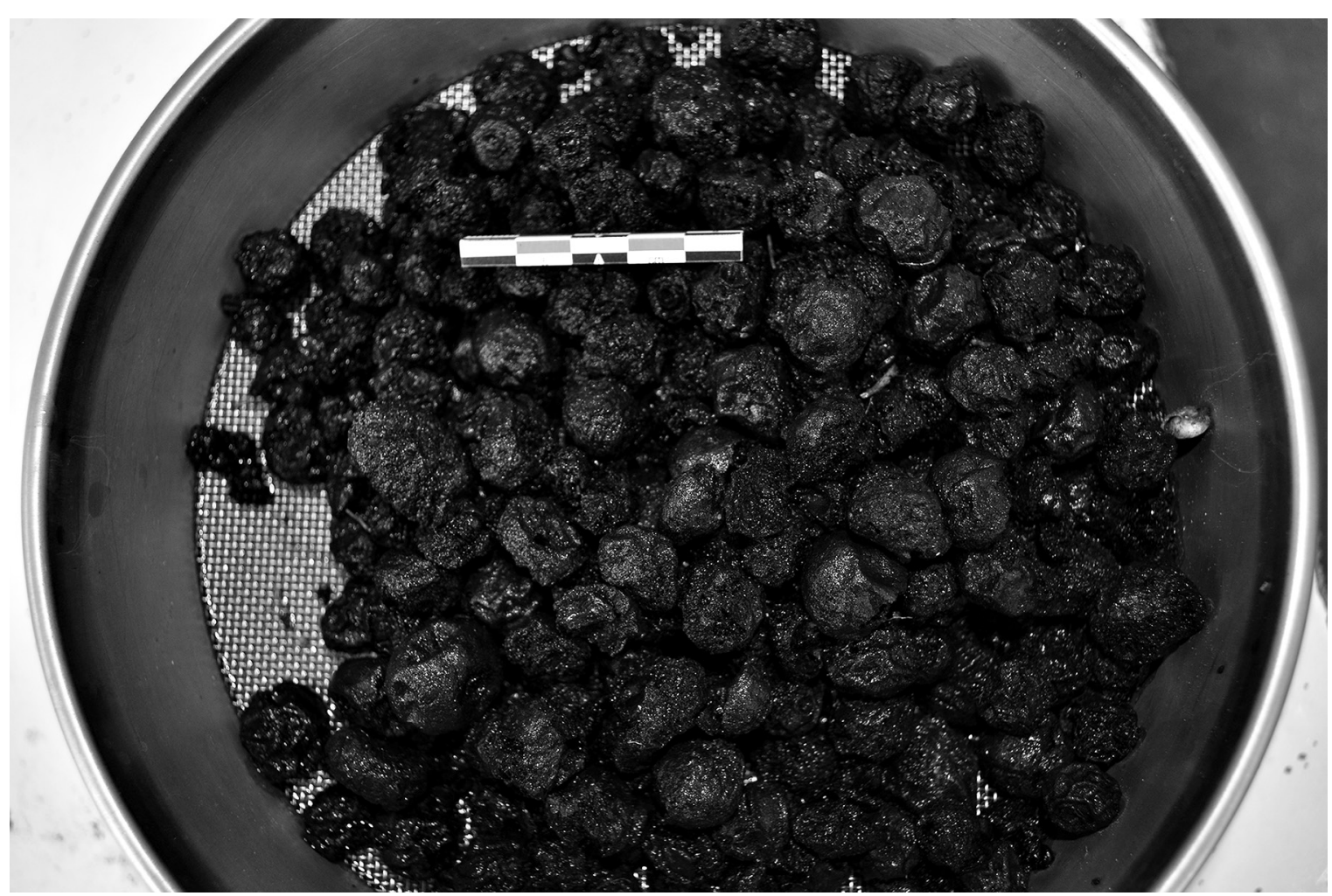

Figure 17. Fruits of wild pear, cf. Pyrus amygdaliformis, from flotation sample from Building 1, Dikili Tash, 2012 excavation season. 


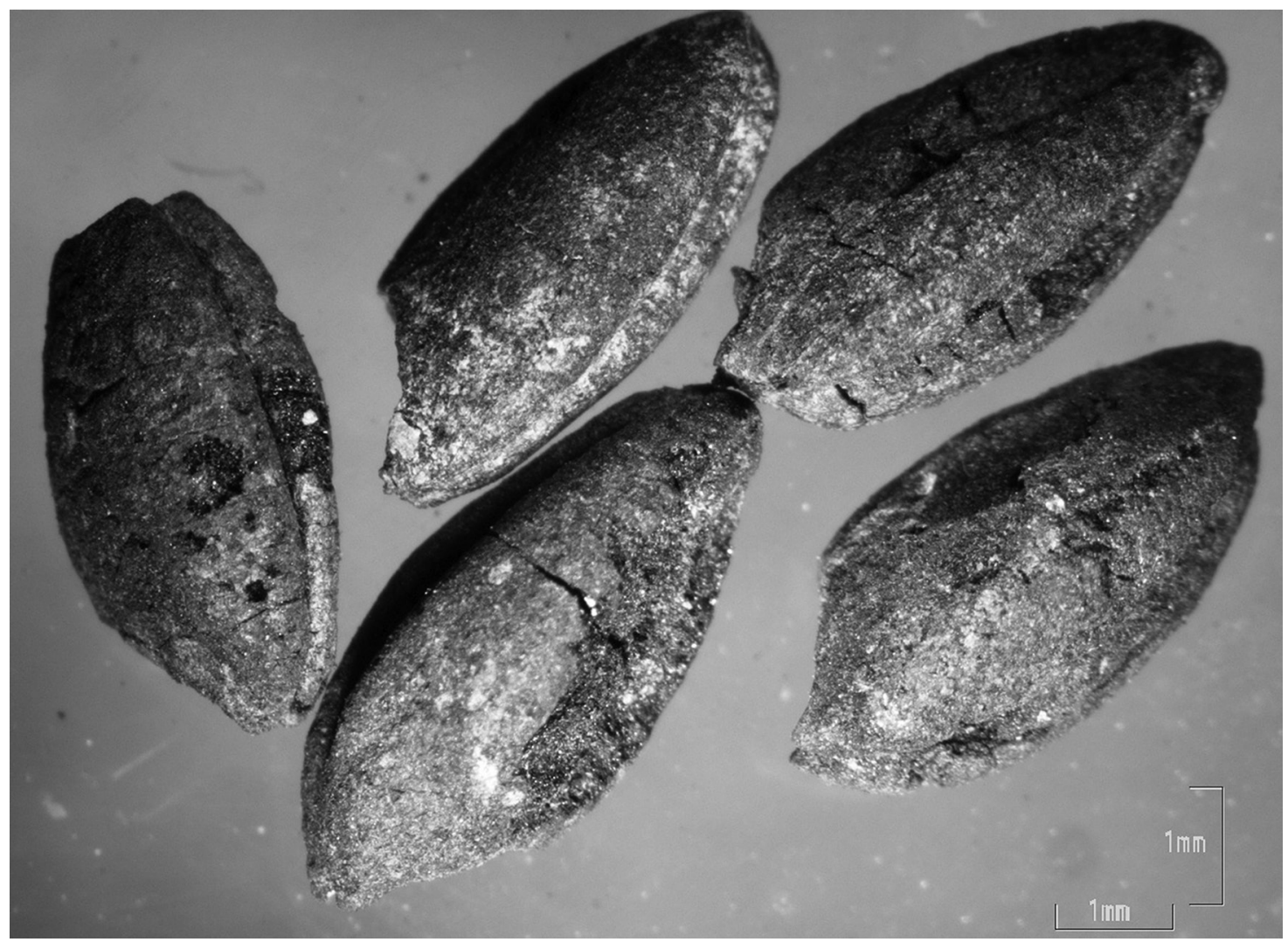

Figure 18. Seeds of einkorn wheat, Triticum monococcum. (Courtesy S. Valamoti)

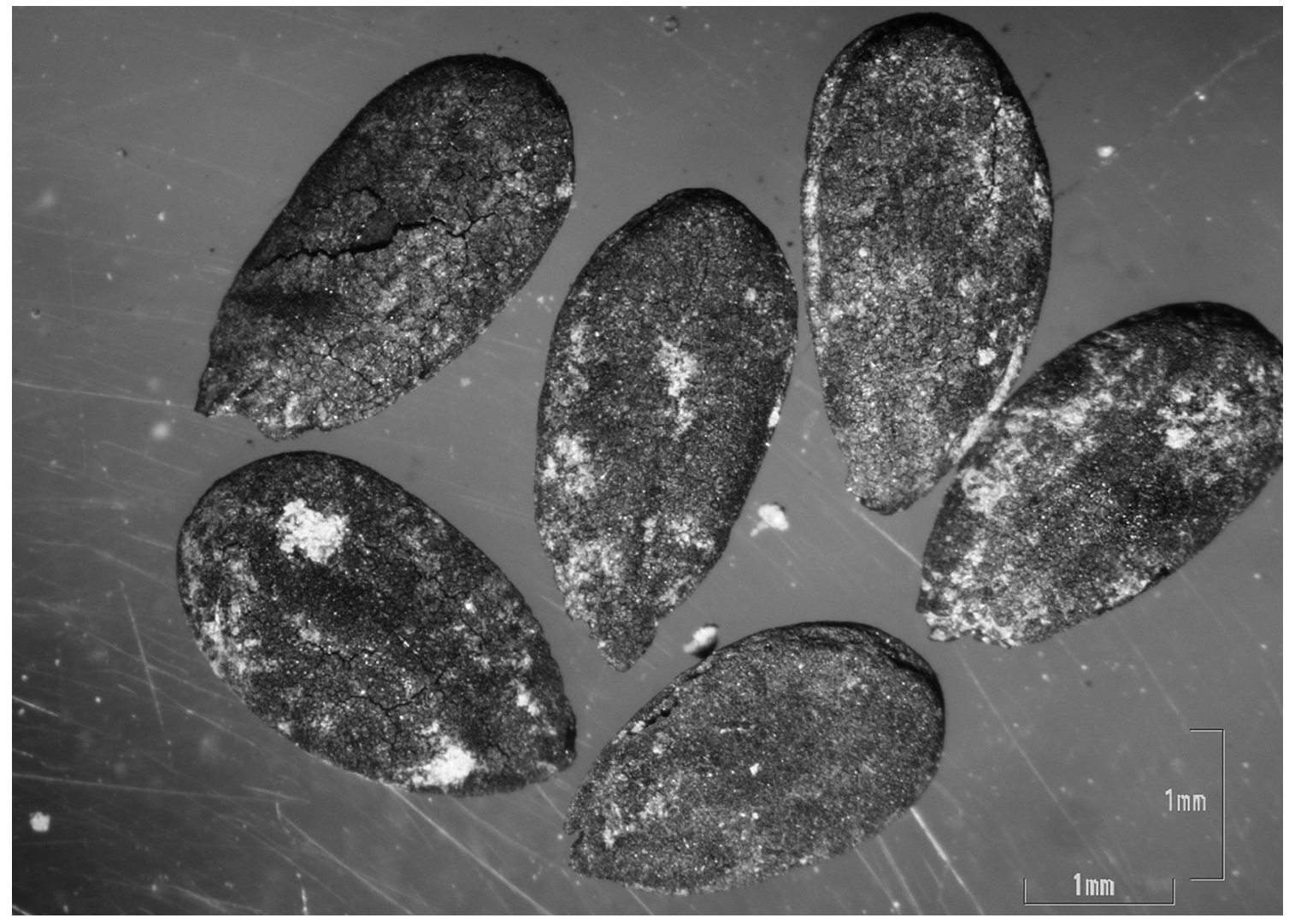

Figure 19. Seeds of flax, Linum usitatissimum, from Building 1. (Courtesy S. Valamoti) 


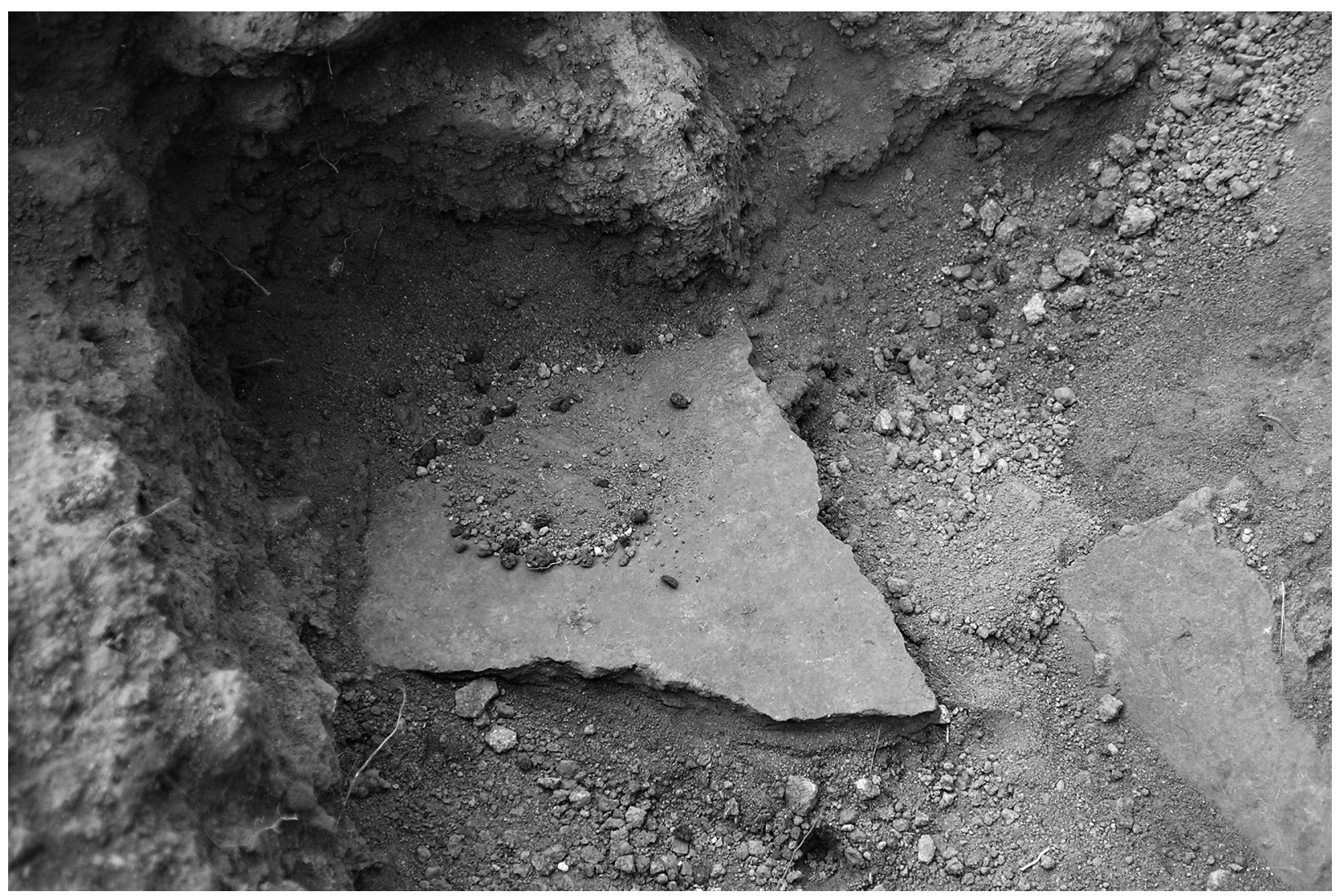

Figure 20. Grape pips and pressings and associated coarse ware vessel in Building 1.

\section{Discussion}

The evidence presented here enables a fresh look at the vegetation exploitation within the context of landscape use by subsistence farmers in Dikili Tash during the LN II. Deciduous oak woodland would have been the most abundant and most frequently managed source for the procurement of firewood for the Neolithic households. The alluvial forests would have been a complementary firewood source. Clearing those forests in order to create pastureland could have provided firewood, which would explain the high proportion of ash in the samples. The presence of taxa from woodland borders and open vegetation could reflect sporadic, day-to-day firewood collection. Their proportions are indicative of their complementary role in the procurement of firewood. Other sources of firewood could have included the remains of woodworking or the special use of certain plants. We mention the remains of vines near Building 4 and stress that the analysis of seed macroremains suggests grape processing activity. Oak tree timbers would have been used for their straight, long trunks and variable caliber branches. Moreover, oak wood is easy to work with and split longitudinally, while ash wood is flexible and hard, hornbeam wood is dense, and juniper wood is very resistant to putrefaction. All the shrub taxa are characterized by a flexible wood and the possibility of obtaining branches of regular caliber when coppiced, which would have been especially useful for the wattle-and-daub technique. The anthracological evidence does not show any differentiation in the selection of timber or the fuel procurement strategies between the four buildings. The evidence from the ongoing study of the architectural remains fits with these findings.

Storage facilities of great capacity are present in each household within all four buildings of Sector 6, such as at least one very big ceramic jar in Building 3, several very big raw clay jars in Building 4, and at least four big ceramic jars in Building 1. Nevertheless, the archaeobotanical remains in Building 1 are particularly large compared to those from the other households. It is not clear whether these discrepancies in archaeobotanical assemblages reflect an actual difference in the function or status of the households, or result simply from differences in the exact time or conditions of destruction. Based on the simultaneous presence of great quantities of late summer or early autumn crops, we can almost be certain that Building 1 was destroyed in the autumn or winter, when the "cellars" were full (Valamoti 2015). It is not clear 
whether the other buildings in Sector 6 were destroyed simultaneously, i.e. by the same conflagration, or by different events that were close chronologically.

The combined study of architectural data, plant macroremains, and charcoal from the buildings shows that their inhabitants exploited a wide range of plant species - both cultivated crops and wild trees - for food, fuel, craftwork, and construction. They were exploiting different niches of the surrounding vegetation, including riparian environments where the grape vines that yielded the numerous grape remains at the site would have grown. Regarding the people-plant relationship, the Dikili Tash finds suggest intensive use of wild fruit or even some form of early fruit tending, at least for some species, or incipient cultivation during the second half of the fifth millennium.

Such intensive interference with woodland vegetation around the settlement, although of a scale undetectable by regional pollen diagrams, seems to be shown in recent environmental proxies from the periphery of the settlement. In fact, Cerealia pollen, which was recorded at the bottom of the archaeological site during recent coring and was associated with other pollen and non-pollen indicators, shows that the first forest clearings occurred in the Early Neolithic, more specifically since $6500 \mathrm{cal}$ B.C. It seems that the first settlers managed to clear the local woodland vegetation that persisted until that time on the edges of the marsh, as the core from the Tenaghi-Philippon marsh shows (Glais et al. 2016). Therefore, the process of landscape modification due to human action began here with the onset of the Neolithic and continued almost uninterruptedly until around 1200 B.C. (the end of the Bronze Age).

The ongoing study of the rich excavation material from Dikili Tash, combined with the geomorphological and palynological data, will certainly further develop our understanding of the interaction between human societies and their natural environment during the prehistoric period.

\section{Notes}

${ }^{1}$ All photographs are from the Dikili-Tash excavation archives, unless otherwise noted.

${ }^{2}$ The first was directed by Dimitrios R. Theocharis and Jean Deshayes; the second by Haïdo KoukouliChryssanthaki and René Treuil.

${ }^{3}$ This new program is directed by Haïdo KoukouliChryssanthaki, Pascal Darcque, Dimitra Malamidou, and Zoï Tsirtsoni. The research between 2008 and 2012 was supported by the following institutions: the Archaeological Society at Athens, the French School at Athens, the French Ministry of Foreign Affairs, the Institute for Aegean Prehistory (INSTAP), the National Geographic Society, the French National Centre for Scientific Research (CNRS, UMR 7041-Nanterre and UMR 5138-Lyon), the French National Research Agency (ANR) - Program "Balkans 4000," and the Municipality of Philippi-Kavala.

${ }^{4} \mathrm{~A}$ full presentation of the history of research, as well as a complete and up-to-date bibliography, is provided on the Dikili Tash website: http://www.dikili-tash.fr. ${ }^{5}$ All dates discussed in this paper are given at a calibration of 2 sigma.

\section{References Cited}

Borojević, Ksenija, and Rebecca Mountain

2013 Microscopic Identification and Sourcing of Ancient Egyptian Plant fibres using Longitudinal Thin Sectioning. Archaeometry 55(1):81-112.

Bottema, Sietse

1974 Late Quaternary Vegetation History of Northwest Greece. Ph.D. dissertation, University of Groningen.

Darcque, Pascal, Haïdo Koukouli-Chryssanthaki,

Dimitra Malamidou, René Treuil, and Zoï Tsirtsoni

2007 Recent Researches at the Neolithic Settlement of Dikili Tash, Eastern Macedonia, Greece: An Overview. In The Struma/ Strymon River Valley in Prehistory: Proceedings of the International Symposium Strymon Praehistoricus, Kjustendil-Blagoevgrad (Bulgaria) and Serres-Amphipolis (Greece), edited by Henrieta Todorova, Mark Stefanovich, and Georgi Ivanov, pp. 247-256. Gerda Henkel Stiftung, Sofia.

2011 The Chalcolithic Period atDikili Tash(Eastern Macedonia, Greece). In The Golden Fifth Millennium: Thrace andits Neighbour Areas in the Chalcolithic, edited by Yavor Boyadzhiev and Stoilka Terzijska-Ignatova, pp. 189-199. Bulgarian Academy of Sciences, Sofia.

Darcque, Pascal, Haïdo Koukouli-Chryssanthaki,

Dimitra Malamidou, and Zoï Tsirtsoni

2009 Dikili Tash. Bulletin de Correspondance Hellénique 133(2):529-541.

2011 Dikili Tash. Bulletin de Correspondance Hellénique 135(2):497-516.

2013 Dikili Tash. Bulletin de Correspondance Hellénique 136/137(2):747-759.

Darcque, Pascal, and Zoï Tsirtsoni

2010 Evidence from Dikili Tash (Eastern Macedonia, Greece) and the Tell Issue. 
In Leben auf dem Tell als soziale Praxis, Beiträge des Internationalen Symposiums in Berlin vom 26-27 Februar 2007, edited by S. Hansen, pp. 55-69. Kolloquien zur Vor- und Frühgeschichte 14. Dr. Rudolf Habelt, Bonn.

Darcque, Pascal, Zoï Tsirtsoni, Haïdo KoukouliChryssanthaki, and Dimitra Malamidou

2015 New Insights to the Copper Age Economy and Chronology at the Tell Settlement of Dikili Tash (Northern Greece). In Neolithic and Copper Age between the Carpathians and the Aegean Sea: Chronologies and Technologies from the 6th to the 4th Millennium BCE, International Workshop Budapest 2012, edited by Svend Hansen, Pál Raczky, Alexandra Anders, and Agathe Reingruber, pp. 403-417. Archäologie in Eurasien 31. Dr. Rudolf Habelt, Bonn.

Darcque, Pascal, Zoï Tsirtsoni, Haïdo KoukouliChryssanthaki, Dimitra Malamidou, Laurent

Lespez, and Cécile Germain-Vallée

2014 The Impact of Environmental Changes on the Neolithic Settlement of Dikili Tash (Northern Greece). In PHYSIS, L'Environnement Naturel et la Relation Homme-Milieu dans le Monde Égéen Protohistorique, Actes de la 14e Rencontre Égéenne Internationale, Paris, Institut National d'Histoire de l'Art (INHA), 11-14 Décembre 2012, edited by Gilles Touchais, Robert Laffineur, and Françoise Rougemont, pp. 425-430. Aegaeum 37. Peeters, Leuven-Liège.

Deshayes, Jean

1974 Fours Néolithiques de Dikili Tash. In Mélanges Helléniques Offerts à Georges Daux, pp. 67-91. E. de Boccard, Paris.

Garnier, Nicolas, and Soultana Maria Valamoti

2016 Prehistoric Winemaking at Dikili Tash (Northern Greece): Integrating Residue Analysis and Archaeobotany, Journal of Archaeological Science 74:195-206. https://doi.org/10.1016/j.jas.2016.03.003

Gärtner, Holger, Sandro Lucchinetti, and Fritz

Hans Schweingruber

2014 New Perspectives for Wood Anatomical analysis in Dendrosciences: The GSL1Microtome.Dendrochronologia 32:47-51. Germain-Vallée, Cécile, Sandra Prévost-

Dermarkar, and Laurent Lespez

2011 Stratégies de Prélèvement et de Mise en œuvre de la "Terre à Bâtir" des Structures de Combustion Néolithiques du site de
Dikili Tash (Grèce) à Partir d'Une Étude Micromorphologique. Archéosciences 35:41-63.

Gimbutas, Marija

1986 Mythical Imagery of Sitagroi Society. In Excavations at Sitagroi: A Prehistoric Village in Northeast Greece, Vol. I, edited by Colin Renfrew, Marija Gimbutas, and Ernestine S. Elster, pp. 225-301. Monumenta Archaeologica 13. Cotsen Institute of Archaeology, University of California, Los Angeles.

Glais, Arthur, José Antonio López-Sáez, Laurent Lespez, and Robert Davidson

2016 Climate and Human-Environment Relationships on the Edge of the TenaghiPhilippon Marsh (Northern Greece) during the Neolithization Process. Quaternary International 401(1):237-250.

Karkanas, Panagiotis, Kosmas Pavlopoulos,

Katerina Kouli, Maria Ntinou, Georgia Tsartsidou, Yorgos Facorellis, and Theodora Tsourou

2011 Palaeoenvironments and Site Formation Processes at the Neolithic Lakeside Settlement of Dispilio, Kastoria, Northern Greece. Geoarchaeology 26(1):83-117.

Koukouli-Chryssanthaki, Haïdo

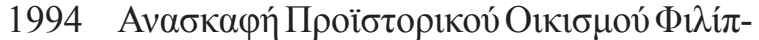

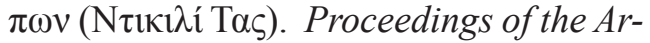
chaeological Societyat Athens 41:123-129.

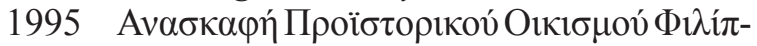
$\pi \omega v(\mathrm{~N} \tau \mathrm{i} \iota \lambda i \mathrm{~T}$ Tas). Proceedings of the Archaeological Societyat Athens 42:109-113.

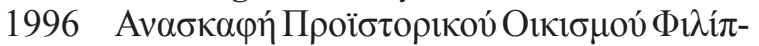
$\pi \omega v(\mathrm{~N} \tau \iota \kappa \imath \lambda i ́ \mathrm{Tac})$. Proceedings of the Archaeological Society at Athens 43:243-245.

Koukouli-Chryssanthaki, Haïdo, Pascal Darcque,

Gilles Touchais, and René Treuil

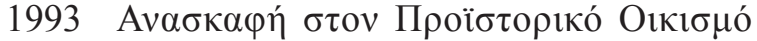

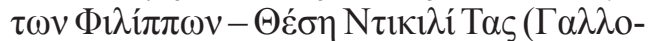

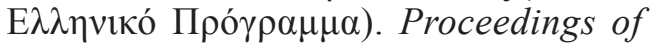
the Archaeological Society at Athens 40:137-150.

Koukouli-Chryssanthaki, Haïdo, and Katerina

Romiopoulou

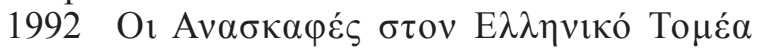

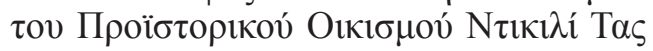
(1961-1967). In $\Delta \imath \varepsilon \theta v \varepsilon \dot{s} \varsigma \Sigma v v \varepsilon ́ \delta \rho \imath o ~ \gamma \iota \alpha$

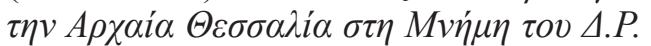

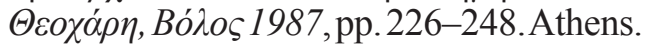

Koukouli-Chryssanthaki, Haïdo, and René Treuil

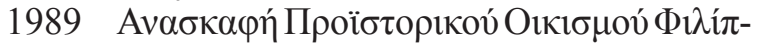

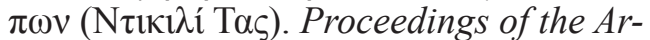
chaeological Societyat Athens 36:232-242. 
Koukouli-Chryssanthaki, Haïdo, and René Treuil (editors)

2008 Dikili Tash, Village Préhistorique de Macédoine Orientale. Recherches FrancoHelléniques Dirigées par la Société Archéologiqued'Athènes et l'École Française d'Athènes (1986-2001). Bibliothèque de la SociétéArchéologique d'Athènes 254. The Archaeological Society at Athens, Athens.

Koukouli-Chryssanthaki, Haïdo, René Treuil, and

Dimitra Malamidou

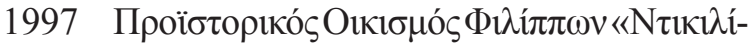

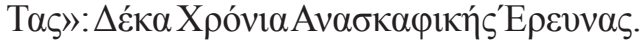
The Archaeological Workof Macedonia and Thrace 10B(1996):681-704.

Lespez, Laurent

2008 L'Évolution des Paysages du Néolithique à la Période Ottomane dans la Plaine de Philippes. In Dikili Tash, Village Préhistorique de Macédoine Orientale. Recherches Franco-Helléniques Dirigées par la Société Archéologiqued'Athènes et l'École Française d'Athènes (1986-2001), edited by Haïdo Koukouli-Chryssanthaki and René Treuil, pp. 21-394. Bibliothèque de la Société Archéologique d'Athènes 254. The Archaeological Society at Athens, Athens.

Lespez, Laurent, Rémi Dalongeville, Claudine Noirel-Schutz, Jean-Pierre Suc, Haïdo KoukouliChryssanthaki, and René Treuil

2000 Les Paléoenvironnements du site Préhistorique de Dikili Tash (Macédoine Orientale, Grèce). Bulletin de Correspondance Hellénique 124:413-434.

Lespez, Laurent, Zoï Tsirtsoni, Pascal Darcque, Haïdo Koukouli-Chryssanthaki, Dimitra Malamidou, René Treuil, Robert Davidson, Georgia Kourtessi-Philippakis, and Christine Oberlin

2013 The Lowest Levels at Dikili Tash, Northern Greece: A Missing Link in the Early Neolithic of Europe. Antiquity 87:30-45.

Mangafa, Maria, and Kostas Kotsakis

1996 ANew Method for the Identification ofWild and Cultivated Charred Grape Seeds. Journal of Archaeological Science 23:409-418.

Maniatis, Yannis, Zoï Tsirtsoni, Christine Oberlin, Pascal Darcque, Chaido Koukouli-Chryssanthaki, Dimitra Malamidou, Tasos Siros, Miltos Miteletsis, Stratis Papadopoulos, and Bernd Kromer

2014 New ${ }^{14} \mathrm{C}$ Evidence for the Late NeolithicEarly Bronze Age Transition in Southeast Europe. In Proceedings of the 38th Inter- national Symposium on Archaeometry, May 10th-14th 2010, Tampa (Florida), edited by Robert H. Tykot, pp. 43-50. Open Journal of Archaeometry 2:5262.

Marangou, Christina

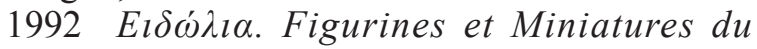
Néolithique Récent et du Bronze Ancien en Grèce. BAR International Series 576. British Archaeological Reports, Oxford.

Martinez, Sylvia

2001 A New Look at House Construction Techniques: Current Research at Dikili Tash, Neolithic Site of Eastern Macedonia. The Archaeological Work of Macedonia and Thrace 13(1999):63-68.

2004 Un Filet de Portage du Néolithique Récent à Dikili Tash (Macédoine Orientale, Grèce). In Approches Fonctionnelles en Préhistoire, Actes du XXVe Congrès Préhistorique de France, Nanterre, 24-26 Novembre 2000, edited by Pierre Bodu and Claude Constantin, pp. 217-222. French Prehistoric Society, Paris.

Martinez, Sylvia, and Sandra Prévost-Dermarkar

2003 Les Techniques deConstruction de l'Habitat en Terre du Site Néolithique de Dikili Tash (Macédoine Orientale, Grèce). Cahier des Thèmes Transversaux ArScAn IV:147-150.

Ntinou, Maria

2002 El Paisaje en el Norte de Grecia desde el Tardiglaciar al Atlantico. Formaciones Vegetales, Recursos y Usos. BAR International Series 1038. British Archaeological Reports, Oxford.

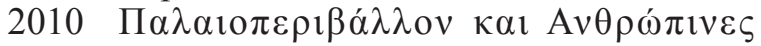

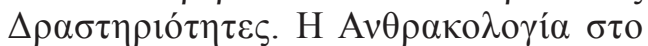

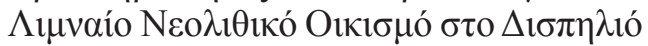

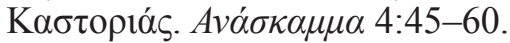

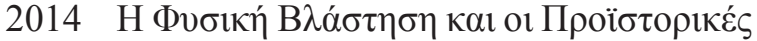

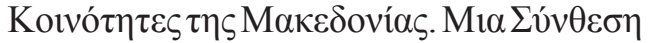

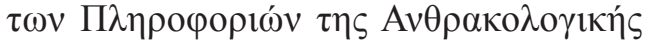
'Epevvas. In 1912-2012: A Century of Research in Prehistoric Macedonia. Proceedings of the International Conference, Archaeological Museum of Thessaloniki, 22-24 November 2012, edited by Evangelia Stefani, Nikos Merousis, and Anastasia Dimoula, pp. 409-418. Archaeological Museum of Thessaloniki, Thessaloniki.

Papadopoulou, Evanthia, and Sandra PrévostDermarkar

2007 "Il n’y a pas de Cuisine sans Feu": Une Approche des Techniques Culinaires au Néolithique et à l'Âge du Bronze à Travers 
les Structures de Combustion en Grèce du Nord. In Cooking up the Past: Food and Culinary Practices in the Neolithic and Bronze Age Aegean, edited by Christopher Mee and Josette Renard, pp. 123-135. Oxbow Books, Oxford.

Prévost-Dermarkar, Sandra

2002 Les Foyers et les Fours Domestiques en Égée au Néolithique et à l'Age du Bronze. In Pains, Fours et Foyers des Temps Passés. Archéologie et Traditions Boulangères des Peuples Agriculteurs d'Europe et du Proche-Orient, edited by Karl Fechner and Marianne Mesnil, pp. 223-237. Civilisations 49. Free University of Brussels, Brussels.

Roque, Céline, Pierre Guibert, Emmanuel

Vartanian, Françoise Bechtel, René Treuil, Pascal

Darcque, Haïdo Koukouli-Chryssanthaki, and

Dimitra Malamidou

2002 The Chronology of the Neolithic Sequence at Dikili Tash, Macedonia, Greece: TL Dating of Domestic Ovens. Archaeometry 44:613-633.

Treuil, René (editor)

1992 Dikili Tash, Village Préhistorique de Macédoine Orientale, I. Fouilles de Jean Deshayes (1961-1975), Vol. 1. Bulletin de Correspondance Hellénique Supplément 24. École Française d'Athènes, Athens.

2004 Dikili Tash, Village Préhistorique de Macédoine Orientale, I. Fouilles de Jean Deshayes (1961-1975), Vol. 2. Bulletin de Correspondance Hellénique Supplément 37. École Française d'Athènes, Athens.

in press Dikili Tash, Village Préhistorique de Macédoine Orientale, I. Fouilles de Jean Deshayes (1961-1975), Vol. 3. Bulletin de Correspondance Hellénique Supplément. École Française d'Athènes, Athens, in press.

Tsirtsoni, Zoï

2016 The Late Neolithic II (Chalcolithic)-Early Bronze Age Transition at the Tell of Dikili Tash. In The Human Face of Radiocarbon:
Reassessing Chronology in Prehistoric Greece and Bulgaria, 5000-3000 cal BC, edited by Zoï Tsirtsoni, pp. 271-298. Travaux de la Maison de l'Orient et de la Méditerranée 69, Lyon.

Turner, Judith, and James A. R. Greig

1986 Vegetational History. In Excavations at Sitagroi: A Prehistoric Village in Northeast Greece, Vol. I, edited by Colin Renfrew, Marija Gimbutas, and Ernestine S. Elster, pp. 44-54. Monumenta Archaeologica 13. Cotsen Institute of Archaeology, University of California, Los Angeles.

Valamoti, Soultana Maria

2004 Plants and People in Late Neolithic and Early Bronze Age Northern Greece: An Archaeobotanical Investigation. BAR International Series 1258. British Archaeological Reports, Oxford.

2015 Harvesting the 'Wild'? Exploring the Context of Fruit and Nut Exploitation at Neolithic Dikili Tash, with Special Reference to Wine. Vegetation History and Archaeobotany 24:35-46.

Valamoti, Soultana Maria, Pascal Darcque, Haïdo Koukouli-Chryssanthaki, Dimitra Malamidou, and Zoï Tsirtsoni

2015 An Archaeobotanical Investigation of Prehistoric Grape Vine Exploitation and Wine Making in Northern Greece: Recent Finds from Dikili Tash. In Olive Oil and Wine Production in Eastern Mediterranean during Antiquity, International Symposium Proceedings, 17-19 November 2011, Urla -Turkey, edited by Adnan Diler, Kaan Şenol, and Ümit Aydinoğlu, pp. 125-139. Ege Üniversitesi Yayınları, İzmir.

Valamoti, Soultana Maria, Maria Mangafa, Haïdo

Koukouli-Chrysanthaki, and Dimitra Malamidou

2007 Grape-Pressings from Northern Greece: The Earliest Wine in the Aegean? Antiquity 81:54-61.

Wijmstra, Tiete Alexander

1969 Palynology of the First 30 Metres of a 120 $\mathrm{m}$ Deep Section in Northern Greece. Acta Botanica Neerlandica 18:511-527. 


\section{Plate I}
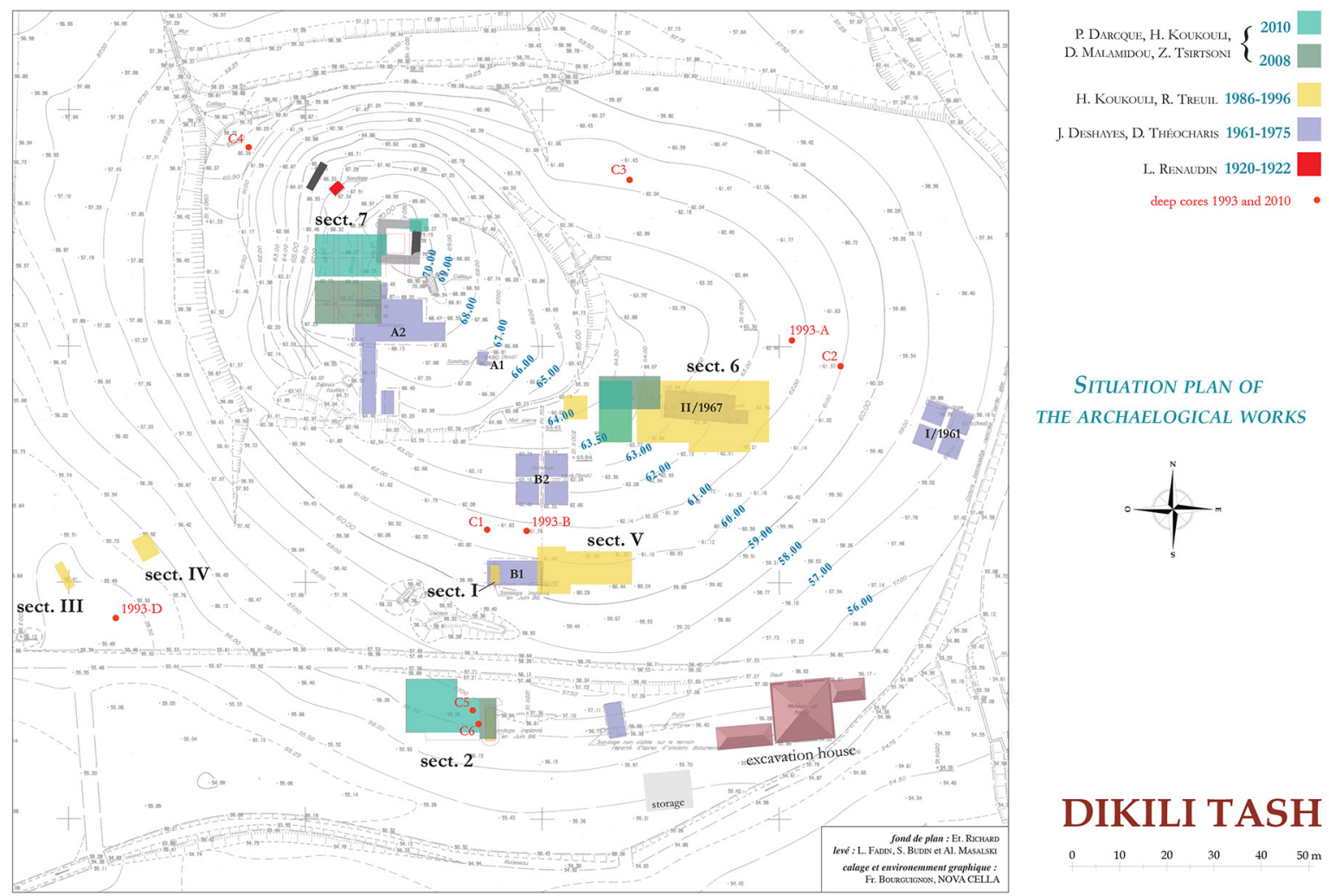

SITUATION PLAN OF THE ARCHAELOGICAL WORKS

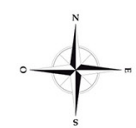

\section{DIKILI TASH}

Chapter 5, Figure 3. Topographical plan of the tell of Dikili Tash, showing the excavation trenches.

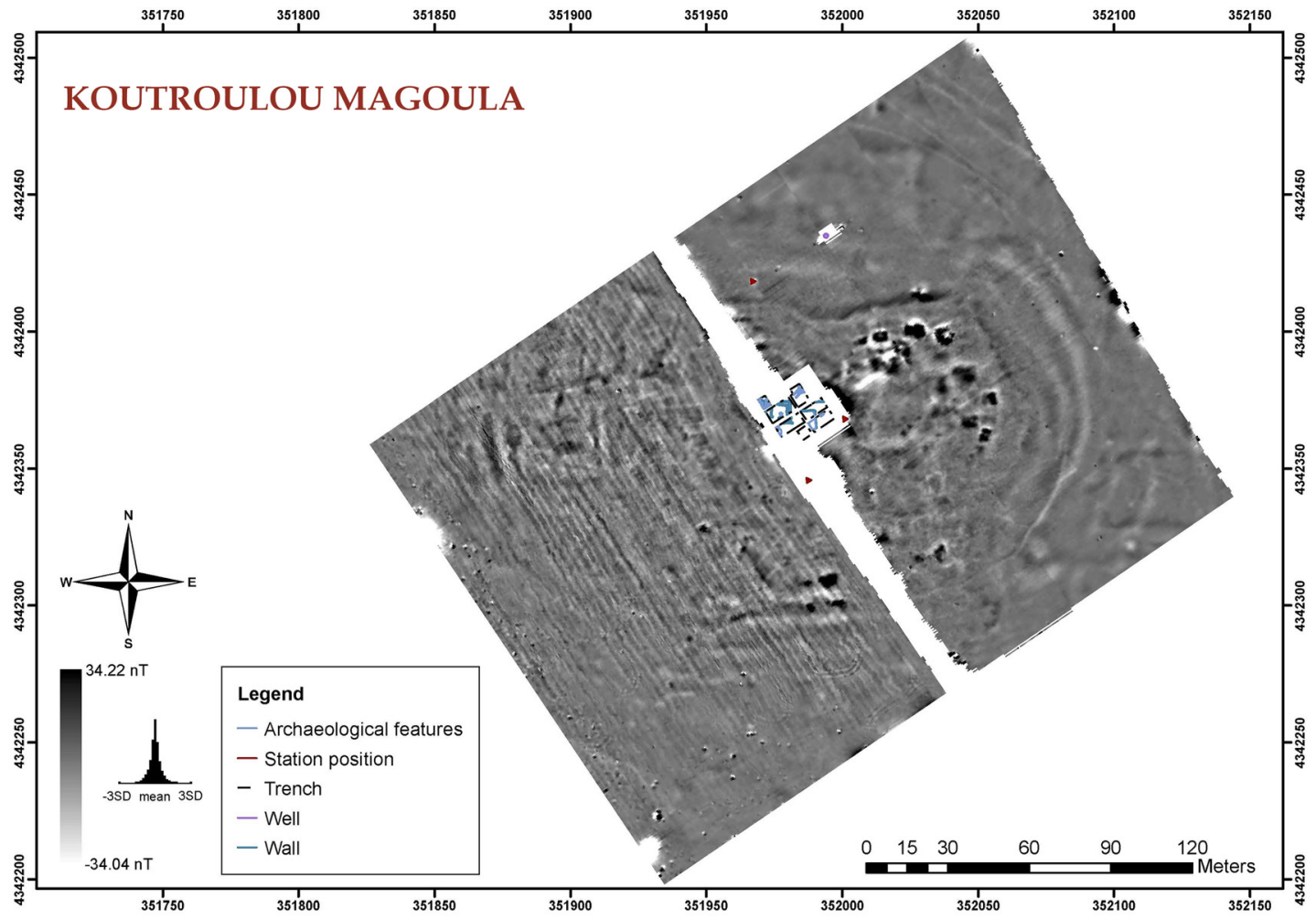

Chapter 6, Figure 3. Results of the magnetometer survey at Koutroulou Magoula (2012). 